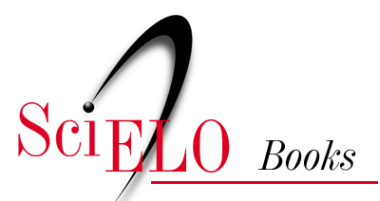

\title{
Clássicos \& Comentários
}

7 - Amilcar Viana Martins, Valdemar Versiani \& Antonio A. Tupinambá - Sobre 25 casos agudos de moléstia de Chagas observados em Minas Gerais.

\author{
José da Rocha Carvalheiro \\ Nara Azevedo \\ Tania C. de Araújo-Jorge \\ Joseli Lannes-Vieira \\ Maria de Nazaré Correia Soeiro \\ Lisabel Klein \\ (orgs.)
}

\section{SciELO Books / SciELO Livros / SciELO Libros}

CARVALHEIRO, J. R., AZEVEDO, N., ARAÚJO-JORGE, T. C., LANNES-VIEIRA, J., SOEIRO, M. N. C., and KLEIN, L., eds. Amilcar Viana Martins, Valdemar Versiani \& Antonio A. Tupinambá - Sobre 25 casos agudos de moléstia de Chagas observados em Minas Gerais. In: Clássicos em Doença de Chagas: histórias e perspectivas no centenário da descoberta [online]. Rio de Janeiro: Editora FIOCRUZ, 2009, pp. 231-306. ISBN: 978-6557-08-101-3. https://doi.org/10.7476/9786557081013.0012.

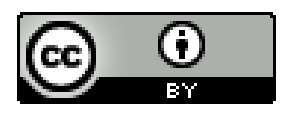

All the contents of this work, except where otherwise noted, is licensed under a Creative Commons Attribution 4.0 $\underline{\text { International license. }}$

Todo o conteúdo deste trabalho, exceto quando houver ressalva, é publicado sob a licença $\underline{\text { Creative Commons }}$ Atribição 4.0.

Todo el contenido de esta obra, excepto donde se indique lo contrario, está bajo licencia de la licencia Creative Commons Reconocimento 4.0. 


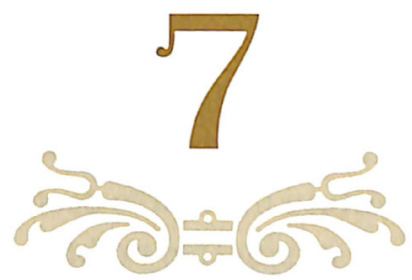

\section{Amilcar Viana Martins,} VALDEMAR VERSIANI \& ANTONIO A. TUPINAMBÁ

Sobre 25 casos agudos de moléstia de Chagas observados em Minas Gerais.

Separata de Memórias do Instituto

Biológico Ezequiel Dias, 3-4: 1-47, 1939-1940. 


\section{Amilcar Viana Martins (1907-1990)}

Médico nascido em Minas Gerais, chefiou o Serviço de Endemias Rurais da Secretaria de Saúde do Estado e foi diretor do Departamento Nacional de Endemias Rurais (DNERu). Dirigiu o Instituto Oswaldo Cruz de 1958 a 1960. A descrição de 25 casos agudos da doença de Chagas em Bambuí constituiu um marco decisivo para a afirmação efetiva da moléstia como importante problema de saúde pública para o Brasil e para a América Latina.

\section{Valdemar Versiani dos Anjos (1901-1980)}

Médico e escritor bissexto, mineiro, trabalhou com Amilcar Viana Martins e Antonio Augusto Tupinambá na descrição de 25 casos agudos da doença de Chagas em Bambuí.

\section{Antonio Augusto Tupinambá (s.d.)}

Médico mineiro, foi professor da Universidade Federal de Minas Gerais e trabalhou com Amilcar Viana Martins e Valdemar Versiani dos Anjos na descrição dos 25 casos agudos da doença de Chagas em Bambuí. Destacou-se ainda pela descoberta de uma nova espécie de barbeiro, a Ponstrongilus tupinambai. 
SEPARATA DAS

"MEMORIAS DO INSTITUTO EZEQUIEL DIAS"

ANOS $1939 \mathrm{E}$ I940 TOMOS III \& IV

\title{
Sobre 25 casos agudos de molestia de Chagas observados em Minas Gerais
}

\author{
1 - Introdução e comentarios, pelos Drs. A. Viana Martins, Val- \\ demar Versiani e Antonio A. Tupinambá.
II - Observações, pelos Drs. Antonio Torres Sobrinho, Antonio Torres, José Elias Lasmar, Ananias Ataliba Teixeira, A. Viana Martins, Valdemar Versiani e Antonio A. Tupinambá.

\section{$\star \star$}

Trabalhe do Instituto Biologico Ezequiol Dias (Dirotor; Profo Otavio Magalhães) - do Sorviço do Estudos das Grandes Endemias do Ings: tituto Osvaldo Cruz. (Superintendente interino: Prof. Carlos Chagas Filho.) - Entregue para publicação em margo do 1942 


\section{SOBRE 25 CASOS AGUDOS DE MOLESTIA DE CHAGAS OBSERVADOS EM MINAS GERAIS}

I - Introdução e comentarios, pelos Drs. A. Viana Martins, Valdemar Versiani e Antonio A. Tupinambá.

II - Observações, pelos Drs. Antonio Torres Sobrinho, Antonio Torres, José Elias Lasmar, Ananias Ataliba Teixeira, A. Viana Martins, Valdemar Versiani e Antonio A. Tupinambá. 
Em trabalho anterior, publicano no $n .^{\circ} 51$, ano LIX, Dezembro de 1940, do "Brasil-Médico", Martins e Tupinambá descreveram resumidamente dois casos agudos da molestia de Chagas, observados em Minas Geraist.

Em nota áquele trabalho, foi dito que mais tres casos haviam sido registrados nos municipios de Bamibuí e Luz, na zona Oeste do Estado de Minas e que seriam oportunamente dados a publicidade.

Desde então se têm multiplicado esses ca๖us, que constituem o objeto da presente publicação, na qual englobamos todas as observações por nós registradas, até Dezembro de 1941.

Vem isso provar sobejamente a afirmativa, tantas vezes repetida, de que casos agudos da molestia de Chagas ocorrem em elevado número em grande parte do território nacional, mas deixam de ser diagnosticados exclusivamente porque os clínicos do interior, a cujas mãos vão eles ter, na sua quasi totalidade, não têm sido suficientemente esclarecidos sobre o assunto.

Hoje, felizmente, graças antes ae tudo ao gigantesco trabalho executado pelos pesquizadores argentinos, com Salvador Mazza à frente, vêm se processando salutar reação. Estudos sobre o tripanosomose americana estão sendo feitos, não só no Instituto Oswaldo Cruz, onde, aliás, nunca sofreran. interrupção, como ainda no Rio Grande do Sul, São Paulo, Goiás, Pará, Minas Gerais, Pernambuco, Baía, etc.. Já começa a molestia a chamar novamente a atenção dos poderes publicos e a entrar nas cogitaçẽes dos clinicos, principalmente do interior.

Consideramos urgente mostrar a verdadeira importancia da molestia de Chagas, provar objetivamente, por meio de 
cbservações numerosas, que não se trata de molestia rara, curinsidade nosologica, que ataca esporadicamente sertanejos de baixo nivei economico, residentes em regiões distantes e pnuco produtivas. Para isso não basta fazer calculos teoricos sobre o numero de cafuas existentes no Brasil e sobre a percentagem de seus habitantes que devem estar infetados.

E' preciso demonstrar a existenc1a do inseto transmissor infetacio na maior parte do territorio nacional; verificar a percentagem de individuos doentes, com a forma cronica, em diferentes regiões; esclarecer os clinicos, afim de que sejam diagnosticados e devidamente registrados os casos agudos, no maior numero possivel. E' necessario divulgar amplamente que o diagnostico da molestia, pelo menos na sua fase aguda, não é apanagio de laboratoristas, pois que ela apresenta sintomatologia um tanto polimorfa talvez, mas com elementos seguros e constantes, que permitem perfeitamente fazer o diagnostico clinico, que só necessitará do laboratorio para sua confirmação. $\mathrm{E}$ então agora, com as esperanças que surgem quanto à terapeutica, esse diagnostico se impõe a todos os clinicos realmente bem intencionados.

E' esse o programa que em Minas Gerais vem sendo executado, com a cooperação e o apoio do governo estadual, pelo Serviço de Estudos das Grandes Endemias, do Instituto Oswaldo Cruz. Os resultados obtidos têm sido absolutamente animadores. Na zona mais trabalhada - o municipio de Bambuî - já o diagnostico clinico e mesmo a sua confirmação pelas provas de laboratorio, é feito com a maior segurança pelos medicos locais, o mesmo acontecendo em outras partes do Estado como, por exemplo, São Gotardo, de onde registramos um caso que veio às nossas mãos apenas para confirmação, já com o diagnostico firmado.

Os casos que agora publicamos vêm demonstrar a necessidade imprescindivel e inadiavel da cooperação, no estudo das nossas endemias, entre os tecnicos de laboratorio e os clinicos do interior do país, os quais, quando solicitados, têm se mostra- 
do sempre colaboradores inestimaveis, sempre prontos a dedicar seus poucos minutos de folga a trabalhos de pesquisa.

Em cerca de 2 anos - de Dezembro de 1939 a Dezembro de 1941 - registrámos no Estado de Minas Gerais 25 casos agudos da molestia de Chagas. Desses, 20 ocorreram no municipio de Bambuí, 3 no municipio de Luz, limitante com Bambuí,1 em Rio Paranaiba, na mesma zona Oeste do Estado e 1 em Grão Mogol, na zona Norte.

Verifica-se, portanto, que $80 \%$ dos casos agora publicados provieram de Bambuí e, si juntarmos a esses os 3 casos observados em Luz, nota-se que uma pequena zona do Estado contribuiu com $92 \%$ da nossa casuistica atual.

Dois fatores concorreram para isso. O primeiro é o fato de possuir a cidade de Bambuí um bem rontado hospital, para onde afluem os doentes, principalmente os de parcos recursos, da região e onde os exames são feitos com grande cuidado, possibilitando assim grande precisão nos diagnosticos.

O segundo fator, evidentemente decisivo, é a indiscutivel abundancia da molestia de Chagas nessa zona.

$E^{\prime}$ preciso salientar que todos os doentes, com exceção apenas dos dois primeiros casos já publicados, foram espontaneamente à consulta, não tendo havido da nossa parte procura de enfermos, o que teria, sem a menor duvida, aumentado de muito o numero de casos registrados.

De acordo com os dados que possuimos atualmente, julgamos que é na zona sudoeste do Estado, compreendida entre os municipios de Luz, Ibiá e Araxá e a fronteira de São Paulo, que a molestia de Chagas atinge a sua maior incidiencia. Os triatomideos domiciliares são aí extremamente abundantes e apresentam-se em alta percentagem infetados pelo Schizotrypanum Cruzi. Os casos clinicos da molestia, na sua forma cronica, são encontrados com grande facilidade.

Parece-nos que a molestia de Chagas é mais frequente nessa zona que, por exemplo, na de Lassance, ou pelo menos que alí a fórma aguda é mais grave e, por isso, mais frequentemente diagnosticada. Aliás, na localidade de Alagoas de D. 
Inacia, municipio de Jaboticatubas, às margens do Rio das Velhas, como Lassance, em dois anos de trabalho continuo, não pudemos observar um só caso agudo da molestia, embora mais de $20 \%$ da população albergasse o Schizotrypanun Cruzi, conforme inquerito epidemiologico por nós realizado e que será oportunamente publicado.

Esses fatos mostram que a molestia assume diferentes aspetos nas diversas regiões onde existe, levantando-se assim novos e interessantes problemas, que precisam ser resolvidos o mais rapidamente possivel.

Tudo isso vem acentuar a genialidade do descobridor da moléstia, que, em condiçc̃es particularmente difíceis, conseguiu individualizá-la perfeitamente, assinalando, como faz notar Mazza, todos os sintomas com absoluta precisão, embora nem sempre atribuisse a determinados sinais a importancia que mais tarde se verificou possuirem.

Assim, Chagas viu e registrou o edema palpebral unilateral, sinal esse a que foi posteriormente ligado, com toda a justiça, o nome do pesquizador que mostrou o seu enorme valor diagnóstico, como tambem viu e registrou os chagomas e as esquizotripanides, cuja grande importancia ressalta dos admiraveis trabalhos de Mazza e seus colaboradores.

Em resumo, pouco deixou Chagas para que os seus continuadores fizessem, a não ser a integral confirmação da sua obra, nas' suas partes basicas e essenciais.

Dos 25 casos incluidos no presente trabalho, 15 apresentaram como sintoma inicial da molestia o edema palpebral unilateral ou sinal de Romaña (obs. 1, 2, 3, 4, 5, 6, 14, 15, 16, 18, 19, 20, 22, 23 e 24). Em tres desses casos, porém, (obs. 1, 14 e 18) se notava na palpebra inferior esquerda (obs. 1), na palpebra inferior direita (obs. 14) ou no angulo palpebral interno do lado direito (obs. 18) uma mancha avermelhada, que precedeu o aparecimento do edema palpebral e que foi interpretada como sendo sinal de picada do inseto. Tratava-se, portanto, de chagomas palpebrais de inoculação.

Em tres outros casost (obs. 7, 8 e 13) observou-se tampem 
o edema bi-palpebral unilateral com adenopatia satélite, sendo, porém, o aparecimento desse sinal precedido dos fenomenos gerais. Com as ressalvas impostas pela possibilidade de serem: esses fenomenos gerais manifestações de outras molestias, que não a tripanosomose americana, podemos nesses casos considerar o complexo oftalmo-ganglionar como uma manifestação secundaria da molestia, talvez como chagoma hematogeno de localisação palpebral.

Julgamos, por isso, aconselhavel esclarecer-se definitivamente si deve ser chamado "sinal de Romaña" todo edema palpebral unilateral de origem chagasica ou sómente o edema palpebral que, por não ser precedido por qualquer outro sintoma (sinal de picaca de inseto, fenomenos gerais), indicaria possivelmente a entrada do Schizotrypanum Cruzi através da conjuntiva sã, segundo o ponto de vista inicial de Romaña.

Isso, evidentemente, em nada diminue o valor do sintoma, pois é pela presença do "olho inchado" que e diagnosticada atualmente a grande maioria dos casos agudos da molestia de Chagas. Dos nossos 25 casos, por exemplo, em 18, ou 72,\% foi a sua existencia que levantou a suspeita da molestia, suspeita essa confirmada posteriormente por provas de laboratorio.

Um dos casos (obs. n. ${ }^{\circ} 21$ ) foi diagnosticado pela presença de um chagoma de inoculação na face anterior do antebraço esquerdo.

O exame histopatologico da lesão, feito pelo prof. Otavio de Magalhães, mostrou o aspeto caracteristico descrito por Mazza, tendo sido ainda encontradas leishmanias. O doente apresentava, tambem, tripanosomas no sangue circulante.

Posteriormente observámos outros casos tambem diagnosticados pela presença de chagomas de inoculação, os quais serão oportunamente publicados. Ressalta, assim, o valor desse sintoma, cuja grande importancia foi mostrada por Mazza e seus colaboradores.

O outro sintoma cuja relevancia foi assinalada pela escola chefiada por Mazza, é constituido pelos esquizotripanides, que já registrámos tambem algumas vezes, com aspéto mor- 
biliforme (obs. 7 e 23) ou urticariforme (obs. 17). Recentemente (Março de 1942), a doente da obs. n. ${ }^{\circ} 3$, Maria Albina da Silva, que teve as manifestações agudas da molestia em Outubro de 1940 e já sofrera sarampo ha cerca de tres anos, apresentou-se com febre e erupção morbiliforme pelo corpo, tendo ficado aparentemente bôa com o uso de medicação anti-alergica. Embora não possamos afastar a hipotese de um acidente alheio à tripanosomiase, julgamos possivel tratar-se de uma esquizotripanide morbiliforme tardia.

Esta mesma doente (Maria Albina da Silva) apresentou, no decorrer do periodo agudo da doença, hipertrofia da tireoide, facilmente perceptivel pela inspecção e palpação. Essa hipertrofia regrediu paralelamente com os outros sintomas, conforme se pode verificar pelas fotografias 1 e 2 .

Esse fato, já verificado pelos autores argentinos e uruguaios, principalmente Talice e colaboradores, ver. mostrar que tambem a tireoide pode participar, como havia acentuado Carlos Chagas, do cortejo sintomatico da molestia, impondo uma revisão cuidadosa do assunto, afim de verificar-se exatamente qual a extensão e as consequencias desse acometimento .

Alguns casos (obs. 9, 10,11, 12, 17 e 25) apresentaram-se apenas com edema generalizado, geralmente mais acentuado no rosto, sem qualquer sintoma mais caracteristico. Esses casos, como de costume, foram primeiramente rotulados como impaludismo e sómente o fracasso absoluto da medicação especifica fez pensar em molestia de Chagas. Os exames de sangue, mostrando a ausencia de plasmodios e a presença de tripanosomas, provaram o acerto do ultimo diagnostico.

A confirmação do diagnostico clinico de molestia de Chagas foi feito pelo xenodiagnostico em 2 casos (obs. 1 e 2), pelo encontro de leishmanias no miocardio em um caso (obs. 6) e pelo encontro de tripanosomas no sangue circulante (exame a fresco, gota espessa ou esfregaço) nos demais vinte e dois casos.

Julgamos particularmente interessante a observaçáo n." 20 , pelo fato de ter sido o diagnostico de suspeita feito pelo 
dr. Ananias Atalıba l'eixeira, clinico em São Gotardo, na zona Oeste do Estado, e confirmado pelo encontro do Schizotrypanum Cruzi em esfregaço do sangue da doente, pelo farmaceutico Bento Ferreira dos Santos, tamber. residente em São Gotardo. Mostra esse caso que, como já afirmámos, o diagnostico da molestia de Chagas, no seu periodo agudo pelo menos, pode ser feito perfeitamente pelos clinicos e pequenos laboratorios do interior, sem ser preciso, na maioria dos casos, recorrer aos grandes laboratorios das capitais.

Basta para isso, repetimos, esclarecer a respeito aqueles clinicos que estão em contacto direto com as populações rurais. E' essa obra de propaganda junto aos clinicos do interior que é necessario fazer-se no Brasil. E acreditamos que, para ser inteiramente eficiente, deve essa propaganda ser feita em viagens frequentes pelo interior do país, devendo cada clinico ser visitado pessoalmente, fazendo-se-lhe as demonstrações necessarias, por meio de preparações microscopicas, figuras, projeção de dispositivos, etc.. E esse, como já acentuámos, um dos pontos fundamentais do programa de trabalho em vias de realização, no Estado de Minas Gerais.

Apresentamos aqui os nossos melhores agradecimentos aos Profs. Otavio de Magalhães e Borges da Costa e ao Dr. Cecilio Romaña, pelo valioso auxílio que nos prestaram na execuçáo deste trabalho. 


\section{OBSERVAÇÕES}

\section{OBSERVAÇÃO N. ${ }^{\circ} 1$}

(Drs. A. Viana Martins e A. A. Tupinambá)

T. L. T., sexo masculino, 46 anos, agrimensor, casado tio de um de nós (A. A. T.).

Reside em Montes Claros, em casa confortavel, onde não existem "barbeiros", mas, no exercicio da sua profissão, já tem morado em casas com: esses insetos. Em Dezembro de 1939, em serviço de divisão de terras, no municipio de Grão Mogol, pernoitou varias vezes em casa de "pau a pique", onde erar. os "barbeiros" extremamente abundantes, sendo por eles sugado frequentemente.

Certa manhã notou na palpebra inferior esquerda pequena papula pruriginosa, que atribuiu à picada de algum inseto. Cerca de 4 a 5 dias depois, começou a notar em ambas as palpebras desse lado um edema, que aumentou progressivamente até chegar a impedir completamente a visão. O edera era duro e de coloração arroxeada, não havendo secreção conjuntival. Ao mesmo tempo apareceu febre, com calafrios e insonia, obrigando o paciente a regressar a Montes Claros. Nessa cidade procurou um oculista, que nada encontrou que justificasse a sintomatologia, prescrevendo injeções de Protinjetol, vacinas anti-infecciosas, etc., terapêutica essa que não teve aparentemente influencia sobre a evolução da molestia, que começou a 
regredir no fim de cerca de 30 dias, até desaparecimento completo.

Ao termos conhecimento desse caso, muitos dias após o inicio da molestia, escrevemos ao Dr. Leví Lafetá, Chefe do Centro de Saude de Montes Claros, pedindo-lhe que nos enviasse a historia clinica do doente, uma fotografia do mesmo e gotas espessas de sangue, remetendo-lhe ao mesmo tempo 5 larvas limpas de $P$. megistus para xenodiagnostico. Quando, porém., aquele ilustre colega entrou em contacto com o paciente, já havia desaparecido o edema, bem como a febre, de modo que foi julgada inutil a fotografia. Tambem as gotas espessas recebidas não se mostraram satisfatorias. Quanto aos "barbeiros" com que foi feito o xenodiagnostico, foram confiados a um laboratorista local, que posteriormente nos comunicou ter sido o mesmo positivo, sem precisar a data do exame, nem o numero de "barbeiros" que se infetaram.

Não satisfeitos com essa informação, aproveitámos uma viagem feita por um de nós a Montes Claros, para repetir o xenodiagnostico, que foi realizado em 2-8-1940, isto é, cerca de 9 mêses após o inicio da molestia, utilizando-se 5 larvas limpas de $P$. megistus. Examinadas essas larvas em 11-9-40, uma delas foi encontrada infetada. Parece-nos, portanto, tratar-se de um caso tipico de molestia de Chagas na sua fase aguda, com a porta de entrada cutanea palpebral, sem conjuntivite e acompanhada de sintomatologia caracteristica: edema palpebral unilaterai, febre, etc. .

\section{OBSERVAÇÃO N. ${ }^{\circ} 2$}

(Drs. A. Viana Martins e A. A. Tupinambá)

C. C. S., sexo masculino, com 16 anos, lavrador, solteiro, residente na fazenda das Tabocas, distrito de Córrego d'Anta, municipio de Luz, zona Oeste de Minas Gerais .

No dia 27-7-1940 fomos informados pelo sr. João José Rosa, proprietario da Fazenda das Tabocas, que um dos filhos de um agregado da fazenda apresentava, desde varios dias, acen- 
tuado edema palpebral unilateral, sintoma esse, segundo o nosso informante, bastante frequente na sua zona. Já tendo observado nessa fazenda dois casos da forma cardiaca da molestia de Chagas (um filho e um sobrinho do proprietario), suspeitámos imediatamente tratar-se de um caso agudo de tripanosomiase americana, decidindo visitar o local, o que infelizmente só foi possivel varios dias mais tarde, em 9-8-1940.

Nessa ocasião o doente já quasi não apresentava edema, notando-se apenas ligeiro estreitamento da fenda palpebral esquerda. O ganglio preauricular esquerdo apresentava-se, porém, grandemente hipertrofiado, duro e movel. Temperatura axilar, $37^{\circ}$. Figado e baço um pouco aumentados e dolorosos. Informou o doente que "o olho esteve inchado cerca de um mês, coçando bastante". O edema variava um tanto de intensidade, chegando ás vezes quasi a impedir a visão. Havia secreção amarelada pouco abundante. Como não foi tomada a temperatura, não poude dizer com precisão si teve febre, porém relata que sentia o corpo quente, principalmente à noite, sêde anormal e sensação de abatimento fisico.

A pesquisa de Schizotrypanum Cruzi, em 10 gotas espessas de sangue do doente resultou negativa. Foi feito xenodiagnostico, utilisando-se 6 larvas de Panstrongylus megistus, das quais 4 se infetaram (exame feito em 25-9-1940, isto é, 47 dias após a sucção).

Ao mesmo tempo foi feito xenodiagnostico nas demais pessoas da familia e er. um cão da casa, tendo sido negativo em cinco pessoas e no cão e positivo no menino V. C. S., com 10 anos de idade (1 larva de $P$. megistus em 4 utilizadas). Na residencia do doente (rancho de barro coberto de sapé) foram apanhados 35 exemplares de $P$. megistus ( 1 macho, 4 ninfas $e$ 30 larvas), dos quais 4 estavam infetados pelo $\mathrm{S}$ cruzi (1 ninfa e 3 larvas).

A alta percentagem de barbeiros que se infetaram no xenodiagnostico $(66 \%)$, mostra que os tripanosomas ainda eram relativamente abundantes no sangue circulante, embora fossem negativas as gotas espessas, o que fala evidentemente em fa- 
vor de uma infecção recente. Tratava-se, pois, de um caso agudo benigno da molestia de Chagas, bastante caracteristico, no qual foi a conjuntiva a provavel porta de entrada.

\section{OBSERVAÇÃO N. ${ }^{\circ} 3$ \\ (Dr. Antonio Torres Sobrinho)}

9 - X 1940, Maria Albina da Silva, 11 anos, sexə feminino, morena, brasileira, residente em Lagôa dos Monjolos, a cerca de 2 quilometros da cidade de Bambuí.

Mora em casa de adobes, rebocada, porém mal conservada, coberta de capim, com numerosos barbeiros, muitos dos quais infetados pelo Schizotrypanum cruzi.

Antecedentes pessoais: Sarampo em 1939, verminose.

Doença atual: Começou ha cerca de um mês, com congestão conjuntival do olho esquerdo, acompanhada de secreção, edema das palpebras correspondentes e circunjacencias e certo arroxeamento da região. Cerca de 8 dias depois, apareceram os mesmos fenomenos, porém mais atenuados, no lado direito. Afinal sobrevieram dôr e certo aumento de volume do epigastrio, dôr $n_{0}$ estomago e na região lombar. Acusou febre alta no inicio.

Estado atual: Pele levemente arroxeada em torno do olho esquerdo e um tanto palida, seca e ligeiramente aspera nas demais regicóes do corpo. Edema das palpebras de ambos os lados, porém particularmente pronunciado no lado esquerdo, em que se nota estreitamento da fenda palpebral. Este edema estende-se às zonas vizinhas e é de consistencia elastica, não deixando sinal à compressão. A face apresenta-se bastante infiltrada. Hiperemia acentuada das conjuntivas palpebrais e pouco aparente das conjuntivas oculares do lado esquerdo. Dacrioadenite esquerda. Ganglio preauricular esquerdo aumentado, bem como os retro e sub-maxilares. Ganglios epitrocleanos e axilares aumentados de volume, bem palpaveis, lisos, moveis. Hipertrofia sensivel da tireoide. 
Aparelho respiratorio: nada digno de nota. Pulso - 108; pressão arterial - Max $81 / 2, \mathrm{Mn}$. $41 / 2$; nada mais que chame atenção para o lado do aparelho circulatorio.

Temperatura axilar - 37,4.

Abdomen volumoso e tenso. Dôr à palpação nos hipocondrios e epigastrio. Figado a 2 dedos abaixo do rebordo costal, na linha axilar média.

Edema elastico dos membros inforiores.

A doente esteve internada de 17 de Outubro a 16 de Novembro de 1940, por gentileza do Prof. Borges da Costa, no Instituto de Radium, em Belo Horizonte. Conservou-se geralmente apirética nesse periodo, havendo raras elevações de temperatura, a mais alta das quais foi no dia 2 de Novembro 37,3 .

A maior frequencia do pulso foi de $118, \operatorname{nos}$ dias 1,2 , e 7 de novembro.

Alta a 16 de novembro, com regressão de todos os sintumas, menos a dacrioadenite que zinda persistia.

\section{EXAMES COMPLEMENTARES EFETUADOS}

9 - X - 1940 - Pesquiza de S. cruzi em guta espessa positiva.

22 - X 940 - Hematias - 5.080.000; leucocitos 5.800 ;

Hemoglobina $-65 \%$ (Sahli)

Wassermann-Kolmer - positivo + +

Exame de fezes - ovos de Ascaris lumbricoides e de $\mathrm{Ne}$ cator americanus.

Exame de urina - nada de anormal.

19 - X - 1940 - Leucocitos -9.000 por mmc.

Barbeiros domiciliares:

1 के e 2 \& de $T$. infestans - positivos.

1 oे de $P$. megistus - positivo.

1 h, 2 ninfas e 7 larvas de $T$. infestans - negativos. 
Xenodiagnosticos em pessoas da familia da doente, residentes na mesma casa:

José A. S.

Idalina M. J.

Jeronimo A. S.

Maria A. S.

José A. S. F.

Antonio A. S.

Lazara A. S.

Jesus A. S.

$$
\begin{aligned}
& \text { - } 38 \text { anos - positivo } \\
& \text { - } 36 "-\text { positivo } \\
& \text { - } 16 \text { " - negativo } \\
& \text { - } 14 "-\text { positivo } \\
& \text { - } 11 \text { " - negativo } \\
& \text { - } 9 " \text { - positivo } \\
& \text { - } 3 \text { " - negativo }
\end{aligned}
$$

Xenodiagnostico em animais da casa:

Cadela "Revolta" - negativo.

Cadela "Defesa" - negativo.

Gata "Teteia" - negativo.

Exame ocular efetuado pelo Dr. Geraldo Queiroga, em $25-\mathrm{X}-1940$.

Visão $-\mathrm{OD}=1 ; \mathrm{OE}=1$.

$\mathrm{AO}$ - Reflexos pupilares presentes e normais.

AO - Fundo de olho normal.

$\mathrm{OE}$ - Edema das palpebras, mais pronunciado na palpebra superior, que está deformada em S, cararacteristico das dacrioadenites. Não se percebe à palpação a porção palpebral da glandula. Hiperpigmentação localizada nas palpebras do $\mathrm{OE}$. Ganglios preauriculares infartados à esquerda . Terapeutica:

$36 \mathrm{cc}$. de solução a $3 \%$ do preparado "Bayer 7.602 " em 14 doses, entre 23 de Outubro e 20 de Novembro de 1940.

$$
\begin{aligned}
& \text { OBSERVAÇÃO N. }{ }^{\circ} 4 \\
& \text { (Dr. Antonio Torres) }
\end{aligned}
$$

16 - X - 1940 - José Balduino Rodrigues - 2 anos e 6 meses, sexo masculino, cor branca, brasileiro, residente na fazenda "Araras", municipio de Luz. Há "barbeiros" em sua casa. 
Iniciou-se a doença há cerca de 30 dias, com inchação das palpebras do lado direito e coloração arroxeada da região. $O$ edema acentuou-se gradativamente, até determinar oclusão quasi completa da fenda palpebral. Cerca de duas semanas depois, sobreveiu febre, prostração e inapetência. Ulteriormente ha oito dias - o edema estendeu-se a todo o lado direito da face e atingiu tambem as palpebras esquerdas.

Exame atual: Edema bipaipebral direito, duro e arroxeado. Palpebras esquerdas um tanto infiltradas. Edema duro ao nivel dos membros inferiores. Ganglio retromastoideu infartado. Temperatura $37 .^{\circ}$.

O doente esteve internado no Instituto de Radium, em Belo Horizonte, de 21 de Outubro a 17 de Novembro de 1940. Nesse periodo, a temperatura mais alta observada foi de $37^{\circ}, 8$, na tarde de 4 de novembro; a maior frequência do pulso verificou-se nos dias 2, 5 e 6 de novembro, com 120 pulsações por minuto .

Alta em 17 de novembro de 1940 , com regressão dos sintomas oculares e gerais.

\section{EXAMES COMPLEMENTARES}

16-10-40 Exame a fresco do sangue - presença de Schizctrypanum cruzi.

22-10-40 Pesquiza do $S$. cruzi em gota espessa - positiva. Hematias - 4.860.000.

Leucocitos -9.400

Hemoglobina - 55\% (Sahli)

Valor globular $=0,57$

23-10-40 Exame de urina - nada de anormal.

25-10-40 Exame de fezes - Ovos de A. lumbricoides.

29-10-40 Wassermann-Kolmer - positivo+

17-11-40 Leucocitos - 8.600.

Exame ocular efetuado em 25-10-40, pelo Dr. Geraldo Queiroga: 
O. D. - Edema discreto das palpebras, permitindo ao paciente mantê-las abertas. Conjuntiva e cornea normais.

Barbeiros domiciliares examinados:

3 to e 4 o de $P$. megistus - positivos.

2 s e 2 i de $P$. megistus - negativos.

Tratamento:

$17 \mathrm{cc}$. de sol a $3 \%$ de "Bayer 7.602", por via intramuscular, entre 23 de Outubro e 13 de Novembro de 1940.

\author{
OBSERVAÇÃO N. ${ }^{\circ} 5$ \\ (Dr. Antonio Torres Sobrinho)
}

18 - 10 - 1940 - José Barbosa, sexo masculino, 4 anos, noreno-escuro, residente no povoado "Campos", fazenda dos Quarteis, municipio de Bambuí, distante da cidade pouco mais de 1 quilòmetro.

Mora em casa rebocada, porém mal conservada, coberta de telhas, com numerosos barbeiros, muitos dos quais infetádos pelo S. Cruzi.

Nada de importante quanto aos antecedentes pessoais.

A molestia atual, iniciada no dia 12 de Outubro, manifestou-se por febre, coloração arroxeada e edema das palpebras do olho direito e região adjacente, com secreção conjuntival pouco abundante. Esse edema local acentuou-se em seguida, estendendo-se ao resto do corpo, tendo atingido os pés ha cerca de quatro dias (14-X-1940) .

Apresenta no momento do exame (18-X-1940) pele seca e edema elastico bem perceptível na raiz do nariz, regiões palpebral e periorbicular direitas, que se mostram vermelho-violaceas, e acentuando-se ainda nas pernas e pés, pouco perceptivel no resto do corpo. Do lado direito se nota a fenda palpebral consideravelmente reduzida; secreção conjuntival pouco abundante; cornea e conjuntiva ocular normais, mas conjuntiva palpebral bastante hiperemiada; dacrioadenite.

Ganglio preauricular direito do tamanho aproximado de um grão de milho, dois ou très ganglios submaxilares palpa- 
veis, do mesmo lado, um dos quais do tamanho aproximado de uma amendoa. Do lado esquerdo, um ganglio submaxilar aumentado. Ganglio epitrocleano palpavel, pequeno, à direita . Nada digno de nota quanto aos gangiios inguinais e ao epitrocleano esquerdo.

Figado e baço não aumentados. Lingua bastante saburrosa.

Pulso 95 e tem.peratura $37^{\prime \prime}, 5$, pela manhã, e ás 17 horas temperatura $40^{n}$.

O exame clínico do coração nada revelou de anormal.

Alguns estertores sibilantes e úmidos no pulmão diłeito; coriza; tosse.

O doente esteve internado no Instituto do Radium, em Belo Horizonte, de 21-10 a 17-11-1940, periodo no qual foi de $38^{\prime \prime}, 5$ a temperatura mais alta observada, na tarde de $1.0^{\circ}$ de Novembro. A maior frequencia do pulso foi de 128 , na tarde de 2 de Novembro. Alta em 17 de Novembro, com regressão dos sintomas oculares e gerais.

\section{EXAMES COMPLEMENTARES}

18-10-40 - Exame a fresco do sangue - positivo para S. Cruzi.

19-10-40 - Neutrs. - 33,5\% ; eosin - 1,0; mastz. - 0,5; linf. - 59,5; monos: - 5,5\%.

23-10-40 - Pesquisa de $S$. Crizi em gota espessa - positiva .

Hemoglobina - 55\% (Sahli); hématias 4.400.000; leucocitos - 13.600.

27-11-40 - Leucocitos - 11.000.

22-10-40 - Exame de fezes - quistos E. coli, ovos de A. lumbricoides e Tric. trichiurus.

23-10-40 - Exame de urina - nada de anormal.

29-10-40 - Wassermann-Kolmer - Positivo +

Exame ocular efetuado pelo Dr. G. Queiroga, em 25-101940:

O. D. - Grande edema difuso das palpebras, mais acen- 
tuado na porção supero-ext. da órbita. Não se sente à palpação o endurecimento da porção palpebral da glandula lacrimal, quando inflamada.

Conjuntiva palpebral ligeiramente congesta.

Tratamento:

12 cc. de " 7.602 ", via intra-muscular, do dia 28 de Outubro a 20 de Novembro de 1940 .

Barbeiros domiciliares:

2 a e 1 larva de $\mathrm{P}$ megtistus - positivos.

1 ㅇ de $P$. megistus - negativa .

\author{
OBSERVAC̣̃̃O N. 6 \\ (Drs. Antônio Torres e Antônio Torres Sobrinho)
}

22-10-1940 - Geralda Mota, sexo feminino, 4 anos, côr branca, residente na fazenda "Ingazeiro", município de Bambuí.

Admitida ao ambulatorio do Hospital N. S. do Brasil, em Bambuí, a 22-10-1940.

Nada de interesse quanto aos antecedentes familiares.

Antecedentes pessoais: sofreu sarampo e uma dermatose herpetiforme.

A doença atual começou ha 18 dias, por febre e edema palpebral esquerdo, com coloração roseo-violácea das pálpebras e adjacencias, secreção conjuntival muco-purulenta, do mesmo lado.

Ao exame clínico, efetuado em 22 de Outubro, apresenta ainda as manifestaçc̃es oculares referidas e edema elastico generalizado, mais perceptivel nos pés. Ganglios pre-auricular, parotidiano e submaxilar esquerdos volumosos; inguinais e axilares tambem aumentados; epitrocleano direito pequeno.

Temperatura $-38^{\circ}, 7$, à tarde. Pulso -150 .

Lingua ligeiramente saburrosa. Não há sinais bem pe:ceptiveis de aumento do figado e baço, achando-se este último um pouco doloroso. Ventre distendido e timpanico. Ritm. 
cardiaco acelerado, com bulhas ligeiramente abafadas. Nada de anormal ao exame do aparelho respiratorio.

Em 25 de Outubro foi levada ao Hospital N. S. do Brasil em franca dispnéa cardiaca, com extremidades frias e cianóticas, tendo falecido ao ser medicada. Retiraram-se o coração e fragmentos do figado e do baço, para exame histopatologico.

\section{EXAMES COMPLEMENTARES}

22-10-40 - Pesquisa do S. Cruzi em seis gotas espessas Negativa.

Barbeiros domiciliares examinados:

2 ¿े, 5 q, 3 ninfas e 3 larvas de $P$. megistus -- positivos;

1 linfa e 2 larvas de $P$. megistus - negativos.

Exames histopatologicos efetuados pelo Prof. Otavio de Magalhães.

Laminas 3.718 .

Fixação - Bouin. Inclusão em parafina. Coloração hemalumen - eritrosina - açafrão.

Resultado:

Baço: - Polpa esplenica profusamente hemorragica. Ha mesmo pequenas rupturas nos seios, com fócos de pequenas hemorragias. Desaparecimento quasi completo dos elementos linfoides do orgão. Edéma. Ha numerosos polimorfonucleares.

Figado: Congestão de orgão. Hiperplasia das celulas de Kupéfer e do sistema reticulo-endotelial. Ha nos capilares polimorfonucleares, monocitos e linfocitos. Necrose irregular de celulas hepaticas em varias regiões dos lobulos. Não vimos quistos parasitarios.

Coração: Miocardite intersticial difusa e intensissima, formada de monolobados, numerosos polimorfonucleares e alguns plasmazellen. Si bem que o processo inflamatorio seja difuso, quasi em lençol, ha fócos mais densos, onde ora dominam os polimorfonucleares, ora os monolobados. Em todos esses fócos, a proliferação his- 
tiocitaria é assinalada. Ha muitos quistos de parasitos (com aspeto áe leishmanias) em todos os tamanhos, esparsos pelo parenquima, no centro ou não do processo reacionário. Ha pontos onde a fibra muscular cardiaca tem um aspeto que lembra o da degeneração hialina.

\section{OBSERVAÇÃO N. ${ }^{\circ} 7$ \\ (Dr. Antonio Torres Sobrinho)}

25-10-1940 - Inês Rezende, sexo feminino, 4 anos, brasileira, branca, residente na Fazenda "São Vicente", municipio de Bambuí.

Nada de interesse quanto aos antecedentes familiares. Sofreu varicela, adenite e, mais recentemiente, uma crise convulsiva.

A 25-10-1940, quando veiu à consulta, achava-se no sexto dia da doença, que se iniciou por febre e uma erupção semelhante à do sarampo, generalizada a todo o tegumento cutaneo. Logo depois se verificou uma adenite submentoniana, em seguida à qual se manifestou edema das palpebras direitas e da região adjacente, com coloração vermelho-violacea.

Ao exame objetivo, apresenta rubefação e edema das palpebras direitas e da zona adjacente e hiperemia da conjuntiva palpebral.

Exantema morbiliforme ao nivel das coxas. Temperatura - 40. Lingua saburrosa. Ganglios epitrocleanos esquerdos aumentados de volume.

Como a doente procedia de zona palúdica, foi feita a medicação anti-malarica, enquanto se aguardava o resultado do exame de sangue. Esse tratamento não produziu modificação sobre a febre e o estado geral, que se mantiveram inalterados. O edema palpebral acentuou-se a ponto de não permitir a abertura do olho. Na zona sub-orbitária o edema se tornou mole, de sorte a deixar sinal persistente à compressão. P'ercebeu-se então o aparecimento de um ordeolo na palpebra superior di- 
reita, pelo que se passou ao uso de topicos oculares adequados, sulfanilamida per os e em injeções, Sulfanilvacin, etc. O ordeolo evoluiu rapidamente para supuração franca. Após alguns curativos, nos quais saiu pús abundante, verificou-se diminuição do edema palpebral, melhora do estado geral e queda progressiva da temperatura, que veiu a normalizar-se 5 dias depois.

Voltou à consulta à tarde do dia 6 de Novembro, com $36^{\circ}, 5$ de temperatura, 120 de pulso. Edema elástico da palpebra inferior direita e de parte da face do mesmo lado, a ponto de apagar quasi por completo os sulcos naso e labio-genianos. Ganglios pre-auricular, submaxilares, submentoniano, axilares e inguinais aumentados de volume; pequenos ganglios epitrocleanos palpaveis. Edema duro discreto dos pés e pernas. Figado e baço sem aumento perceptivel. Ausencia de sinais clínicos de importancia, ao exame dos demais orgãos.

A 25 de novembro, quando voltou ao exame o edema da palpebra e da face se havia desvanecido quasi inteiramente. Tanto os ganglios preauriculares de ambos os lados, como os das demais regiões em que são facilmente accessiveis à palpação, se achavam aumentados de volume.

Figado e baço de dimensões normais. Ligeiro edema elastico dos membros inferiores. Temperatura $-36^{\circ}, 7$. Pulso -119 .

$$
\begin{aligned}
\text { 26-11-1940 - } & \text { Temp. } 36^{\circ}, 9 . \text { Pulso }-118 \\
\text { 27-11-1940 - } & \text { Temp. } 37^{\circ} \text { Pulso - } 94 \\
\text { 7- 1-1941 - } & \text { Apresenta ainda ligeira hipercromia da pe- } \\
& \text { le da região afetada, poliadenia pronuncia- } \\
& \text { da e figado aumentado de volume. Tempe- } \\
& \text { ra. }-36,8 .
\end{aligned}
$$

\section{EXAMES COMPLEMENTARES}

25-10-40 - Pesquisa do hematozoario de Laveran em gota espessa - negativa .

Pesquisa de S. cruzi em gota espessa - positiva. 
29-10-40 - Pesquisa de S. cruzi em gota espessa - positiva.

Barbeiros domiciliares examinados:

1 of e 1 o de $T$. infestans - positivos.

1 \& de $T$. infestans - negativo.

\section{OBSERVAÇÃO N. ${ }^{\circ} 8$ \\ (Dr. Antonio Torres Sobrinho)}

4-11-1940 - Sebastião Claudio, 5 anos, branco, residente na fazenda "Sapé", municipio de Bambuí. Ha barbeiros em sua casa.

Admitido ao ambulatorio do Hospital N. S. do Brasil em 4-11-940. A doença iniciou-se cerca de 15 dias antes, com febre e dôres no ventre; 8 dias após o aparecimento desteś sintomas, marifestou-se edema bipalpebral do lado direito, com adenite preauricular.

Foi levado a um farmaceutico, que lhe administrou medicação para malaria. Há três dias se iniciou o edema.

Exame em 4-11-1940 - Edema duro, elastico, bem pronunciado, das palpebras direitas e adjacencias, com coloração vermelho-violacea. Inicio dos mesmos sintomas do lado esquerdo. Hiperemia das conjuntivas palpebrais, mais acentuada à direita. Ganglio pre-auricular direito volumoso, perceptivel mesmo à inspecção, cervicais esquerdos e parotidianos direitos tambem aumentados. Edema duro e elastico dos pés e pernas. Figado discretamente aumentado e doloroso. Baço aumentado, palpavel. Temperatura $-37^{\circ}$. Pulso - 116.

\section{EXAMES COMPLEMENTARES}

4-11-1940 - Pesquisa de S. cruzi em gota espessa positiva.

25-11-1940 - Hematias - 4.830.000.

Leucocitos - 8.200

Hemoglobina - 68\% (Sahii)

Valor globular $=0,70$ 
26-11-1940 - Xenodiagnostico: 6 larvas de P. megistus, examinadas em 9-1-1941 - todas infectadas. Wassermann -Kolmer - negativo.

OBSERVAÇÃO N." 9

(Dr. J. Elias Lasmar)

$3=12=1940$ Elvira Fernandes Coutinho, sexo femini= no, branca, 22 meses, Peso - $8 \mathrm{Kg.,100} \mathrm{grs.} \mathrm{Altura} \mathrm{-} \mathrm{0m,77.}$ Reside em "Capão Escuro", a 2 leguas da cidade de Bambuí. Casa de barro, madeira e capim, separada da habitação mais proxima por uma distancia de 500 metros. A uns 400 mts. está situada a mata, de recente formação.

A casa, construida há 3 anos, tem atualmente grande quantidade de "barbeiros"; o proprietário suspeita que os mesmos vêm do mato.

Doença atual: - Começou no dia 22 de Novembro, com febre e vomitos. No $4 .^{\circ}$ dia apareceu uma inchação generalizada, que chegou ao maximo no $8 .^{\circ}$ dia do inicio da doença. Nesisa epoca o estado da criança era grave, apresentando ela abatimento, sonolencia, edema gereralizado, pulso extraordinariamente frequente e temperatura de $39^{\prime \prime}, 8$. Nos dias subsequentes o estado geral melhorou, baixando a temperatura e desaparecendo progressivamente o edema.

Estado atual - Observada pela primeira vez em Bambuí, no dia 3-12-1940, apresentava sonolencia e grande abatimento, permanecendo indiferente, com os olhos entreabertos. A temperatura atingiu a $39^{\prime \prime}, 8$, havendo edema generalizado por todo o corpo, especialmente visivel ao nivel do rosto e nas palpebras. Esse edema era brando e palido, não conservando a impressão dos dedos. Abdomen consideravelmente distendido, impedindo a bôa palpação. Rêde venosa colateral adbomino-toracica bem evidente. Epigastrio doloroso à palpação. Figado corsideravelmente aumentado de volume, ocupando todo o abdomen superior.

Por suspeita de tratar-se de um caso agudo da doença de 
Chagas, foi feito exame de sangue em gota espessa, que confirmou o diagnostico.

Internada no Hospital Oswaldo Cruz, em Manguinhos, no dia 5 de dezembro.

A 6 de dezembro, apresentava-se desnutrida, agitada, nervosa, chorando continuamente. Estado geral um pouco melhor, com desaparecimento completo do edema, tanto no rosto, eomo no resto do corpo; Observou=se uma estomatite; que se pdía atribuir ao nascimento dos molares; Ganglios cervicais e axilares de pequeno tamanho, inguinaís muito ingurgitados. Nada de particular ao exame do aparelho respiratorio. Ritmo cardiaco muito acelerado, bulhar debeis e distantes; não se percebe arritmia. Figado diminuido em relação ao exame anterior, mas ainda ber: palpavel e doloroso. Baço tambem aumentado de volume, palpavel por baixo do rebordo costal. Rêde venosa colateral ainda visivel. Percebe-se, na região glútea, a formação de um abcesso, causado por infecção feita anteriormente.

A 8 de dezembro observou-se novamente o aparecirnento de um edema generalizado, mais acentuado no rosto e nas palpebras; este edema se conservou aparente cerca de uma semana.

A partir do dia 8, a febre manteve-se ainda por mais de 20 dias, com predominancia vesperal. Temperaturas mais altas observadas: $39^{\circ}, 4$ no dia 7 de dezembro, $39^{\circ}, 3$ no dia 13 e $39^{\circ}, 5$ no dia 21 . De 26 de dezembro em diante, a febre se conservou abaixo de $38^{\circ}$, baixando gradativamente, até completo desaparecimento.

Alta no dia 1 - 1 - 1941 .

\section{EXAMES COMPLEMENTARES}

3-12-40 - Pesquisa de $S$. cruzi em gota espessa - positiva.

Hematias - 3.910.000

Leucocitos - 4.920

Hemoglobina - $45 \%$ (Sahli)

Valor gilobular - 0,68 
Formula leucocitaria

$\begin{array}{lrrrr} & 3-1-40 & 6-1240 & 9-12-40 & 14-12-40 \\ \text { Mielocitos neutrofilos } & 2,0 & 0,0 & 0,0 & 0,0 \\ \text { Polimorfonucleares neutrofilos } & 51,0 & 30,5 & 38,0 & 44,5 \\ \text { Eosinofilos } & 0,0 & 5,0 & 7,0 & 3,5 \\ \text { Pro-linfocitos } & 3,0 & 0,0 & 0,0 & 0,0 \\ \text { Grandes linfocitos } & 30,0 & 24,5 & 15,0 & 8,5 \\ \text { Pequenos linfocitos } & 0,0 & 28,5 & 31,0 & 35,5 \\ \text { Linfocitos histioides } & 4,0 & 0,5 & 0,0 & 0,0 \\ \text { Monocitos } & 4,0 & 8,5 & 8,0 & 6,0 \\ \text { Celulas de Türck } & 4,0 & 1,5 & 0,0 & 1,5 \\ \text { Celulas de Rieder } & 3,0 & 1,0 & 1,0 & 0,5\end{array}$

11-12-1940 Exame de fezes — ovos de A. lumbricoides

Exame de urina:

$$
\begin{aligned}
& \text { Albumina - traços leves } \\
& \text { Glicose - } \text { ausencia } \\
& \text { Sedimento - celulas descamativas; grande } \\
& \text { quantidade de bacterias de fer- } \\
& \text { mentação. }
\end{aligned}
$$

13-12-1940 - Dosagem de cloretos na urina - 12,60 por mil.

\section{Barbeiros domiciliares examinados}

7 de $P$. megistus - positivos

2 o e 3 ㅇ de $P$. megistrs - negativos

Tratamento: $23 \mathrm{cc}$. de sol. a $3 \%$ de "Bayer 7.602", entre os dias 12 e 20 de dezembro.

Formula leucocitaria com reação de oxidase

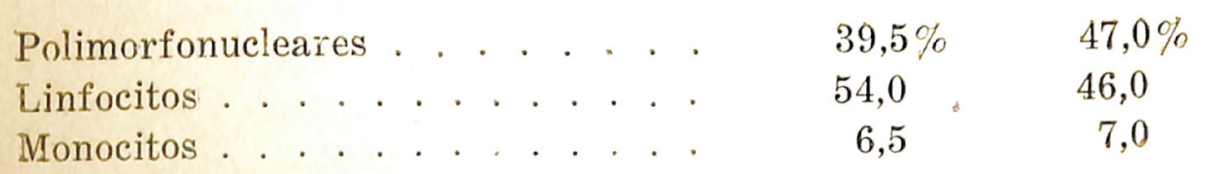

11-12-1940 Biopsia do ganglio inguinal. 
Gangliograma :

Henocitoblastos . . . . . . . . . $30 \%$

Linfoblastos . . . . . . . . . . . . . 4,0

Prolinfocitos . . . . . . . . . . 42,0

Linfocitos . . . . . . . . . . . . 50,0

Celulas plasmaticas . . . . . . . . . 1,0

O exame do gangliograma mostra uma hiperplasia evolutiva tipo comum, segundo a classificação de Pawlosky, sem desvio na morfologia das celulas, que apresentam um aspéto normal.

Exame histologico - (Prof. Magarinos Torres) Hiperplasia generalizada do tecicio linfoide, sem grande aumento dos centros germinativos, com forte infiltração linfoide dos cordões e aparecimento de grande quantidade de celulas histioides no seio dos acumulos linfocíticos.

\section{OBSERVAÇ̃̃O N. ${ }^{\circ} 10$ \\ (Dr. Antônio Torres Sobrinho)}

14-12-1940 - Vicente Pedro Gomes, 6 anos de idade, moreno, brasileiro, residente no local denominado "Lagoa Rasa", municipio de Bambuí. Mora em "cafúa", onde foram encontrados "barbeiros".

Nada digno de nota nos antecedentes familiares. Sofreu coqueluche aos 3 anos e sarampo aos 4 . Expele vermes.

Ha cerca de 20 dias se iniciou a molestia atual, com dôres abdominais e febre, serr edema ocular; a dôr abdominal tem continuado até hoje. Ha 8 dias surgiu edema paipebral que, segundo informa a mãe do paciente, se iniciou concomitantemente em ambos os olhos, estendendo-se logo a todo o corpo, particularmente aos membros inferiores. A febre tem ocorrido diariamente, via de regra com elevação vesperal.

Exame atual: Pele um tanto seca e palido-terrosa, sem aumento apreciavel de pigmentação na região peri-ocular. Conjuntivas palpebrais um tanto congestas, bulbares inalteradas. 
Edema elastico das palpebras, rosto, tronco e membros inferiores, oferecendo o aspecto de edema mixedematoso.

Ganglios preauriculares, retro e submaxilares, cervicais, supraclaviculares, axilares, epitrocleanos e inguinais palpaveis, uns volumosos, outros muito pequenos, mas todos indolores, lisos e moveis.

Ventre volumoso, timpanico. Borda inferior do figado lisa à palpação e a um dedo transverso acima da transversal que passa pela cicatriz umbelical; borda superior para cima d$5 .^{\circ}$ espaço intercostal; o orgão é doloroso à pressão. Em razãc do volume do figado e da tensão abdominal, é dificil o exame do baço .

Temperatura às $8,50 \mathrm{hs}$. da manhã - 37,3; pulso 118 por minuto; respiração - 41 por minuto.

Aparelhos circulatorio, respiratorio, urinario e sistema nervoso sem alterações dignas de nota.

A 21-12-1940, depois de ter usado Sezonan por espaço de uma semana e Hemosplenina, achava-se com $r$ ventre bem mais flacido, figado a cerca de 2 dedos abaixo da reborda costal, à expiração; temperatura $37^{\circ}$, estado geral melhor, edemas quasi desaparecidos.

\section{EXAMES COMPLEMENTARES}

12-12-1940 Pesquiza de S. cruzi no sangue a fresco positiva .

Idem, em gota espessa - positiva .

Xenodiagnostico - positivo (examinados 2

"barbeiros" em 23-1-41, sendo 1 positivo e 1 negativo)

Barbeiros domiciliares examinados:

1 \& e 1 우 de $P$. megistus - positivos.

1 to de $P$. megistus - negativo.

2 \& e 2 아 de $T$. infestans - negativos.

2 e 1 ninfa e 1 larva de $T$. infestans - negativos.

Não foi feita medicação. 
OBSERVAÇÃO N. ${ }^{\circ} 11$

(Dr. J. Elias Lasmar)

26-12-1940 - Antonio Jeronimo de Carvalho, cor branca, 2 anos e 7 mêses, residente em "Posse", a 25 quilometros da cidade de Bambuí. Mora em casa de pau a pique (antigo paiol), onde são encontrados "barbeiros".

Nada de interessante nos antecedentes familiares e pessoais.

Apareceu no consultório com febre de $38^{\circ}, 5$. Fígado bastante aumentado; baço, idem; edema generalizado, duro. Retirado o material para exame e emquanto se esperava pelo resultado, mandei ậiicar Paludam Infantil, injeções de Esplena, comprimidos de Atepê. Depois de alguns dias, chegando aqui, afim de ir a Belo Horizonte, a criança se achava bem melhor, com pouco edema; estado geral, melhorado.

Adoeceu a 5 de dezembro, com febre alta, que se elevava à noite. Após 10 dias, apareceu edema duro, generalizado, que permaneceu por cerca de 10 dias.

O exame clinico, efetuado a 26 de dezembro, revelou um figado a 4 dedos do rebordo costal, baço palpavel, edema duro generalizado e ganglios preauriculares, axilares e inguinais muito infartados. Febre.

Transportado o doente para Belo Horizonte, o exame clinico aqui feito em 12 - jan. 1941 revelou já certa diminuição do volume do figado, que estava percutivel a 2 dedos abaixo do rebordo costal; ganglios preauricular direito, epitrocleano esquerdo, axilares e inguinais palpaveis; pulso - 134'.

\section{EXAMES COMPLEMENTARES}

26-12-40 - Pesquisa de S. Cruzi em gota espessa - positiva.

24- 2-41 - Xenodiagnostico -- 4 larvar de $P$. megistus, examinados er: 24-Z-1941 - todas infetadas. 
12- 1-41 - Exame hematologico: Hematias 4.700.000 por $\mathrm{mm}$.; leucocitos - 11.800 por $\mathrm{mm}$. Hemoglobina - 60\% (Sahli)

13- 1-41 Xenodiagnostico -5 larvas de $P$. megistus, examinadas em 24-2-41 - todas infetadas.

Não foi feito tratamento .

OBSERVAÇÃO N.. 12

(Dr. Antonio Torres)

8 - 1 - 1941 - Juvenal Pinto Alves da Silva, sexo masculino, 8 anos, branco, brasileiro, residente no local denominado "Pedrinhas", município de Bambuí.

O pai teve morte subita ha 8 anos. Mãe viva, portadora de bocio ha varios anos. Nada mais digno de menção quanto aos antecedentes familiares e pessoais.

A presente molestia iniciou-se ha cerca de um mês, com febre, tosse, calafrios, timpanismo abdominal, dôr no epigastrio, profundo abatimento, suores abundantes, artralgias. En: seguida surgiu edema da face e membros inferiores. A febre continuou até 5 dias atrás, tendo sido receitados Sezonan e Hemosplenina, por suspeita de malaria.

Ao exame, apresenta pele seca, palida, pequena turgescencia das palpebras, com coloração rosea esbatida das maçãs do rosto. Gânglio parotidiano direito palpavel com certa dificuldade, aumento dos ganglios cervicais e de um submaxilar do mesmo lado e tambem de alguns submaxilares esquerdos. Axilares de ambos os lados, epitrocieano direito e inguinais aumentados, ligeiramente duros, moveis e lisos. Temperatura $-37^{\circ} ; 114$ pulsações por minutc.

Aparelhos circulatorio, respiratorio e urinario, bem como sistema nervoso, sem sinais que chamem a atenção, ao exame clinico.

Lingua ligeiramente saburrosa, ventre volumoso e timpanico. Figado bem aumentado de volume e doloroso à palpação. Baço palpavel à inspiração (ligeiramente aumentado) . 
A 14-12-1940, voltou o doente à consulta, já com diminuição do volume do figado e do baço. Voltou novamente alguns dias depois, com desaparecimento quasi completo dos sintomas apresentados.

\section{EXAMES COMPLEMENTARES}

3-12-41 - Pesquisa do S. Crazi em gota espessa - positiva.

Tratamento: não foi feito.

Barbeiros domiciliares examinados:

5 o e 1 larva de $P$. megistus - positivos.

5 o 1 \& e 1 larva de $P$. megistus - negativos.

OBSERVAÇ̃̃O N. ${ }^{\circ} 13$

\section{(Dr. Antonio Torres Sobrinho)}

10 - 1 - 1941 - Maria do Rosario Chaves, sexo feminino, 15 meses, branca, residente no bairro do Cruzeiro, cidade de Bambui. Admitida ao ambulatorio do Hospital de N. S. do Brasil, em Bambúí, a 10 - 1 - 1941.

Nada digno de nota, quanto aos antecedentes familiares e pessoais.

A 17-12-1940, mais ou menos, adoeceu com febre, pouca tosse, ventre volumoso, vomitos, em que eliminou ascaris. Cerca de 10 dias após essa molestia febril, surgiu edema do olho direito, que se estendeu poucos dias depois ao resto do corpo.

Veiu ao Hospital, onde, por suspeita de doença de Chagas, foi feita pesquisa de $S$. Cruzi no sangue a fresco, com resultado negativo. Como a temperatura era baixa e satisfatorio o estado geral, ficou em observação, tendo-lhe sido administrado cloreto de calcio.

No dia 5-1-41 voltou com edema mais acentuado, temperatura de $37^{\circ}, 2$ e um abcesso no couro cabeludo. Dilatado o abcesso e feita nova pesquisia a fresco de $S$. cruzi, com re- 
sultado ainda negativo, recebeu a doente medicação para nefrite.

Voltou à consulta hoje (10-1-1941), com $38^{\circ}$ de temperatura e 120 de pulso. Edema palpebral e periocular direito mais pronunciado, coloração róseo-violácea da região malar do mesmo lado. Edema do tronco e membros tambem mais acentuado. Gânglios pre-auricular direito, cervicais, epitrocleanos, axilares e inguinais aumentados. Pequeno aumento do figado e do baço. Os demais aparelhos e sistemas sem: alteração de importância.

A 23-1-1941 foi transportada para Belo Horizonte, onde chegou febril e com estertores de bronquite, apresentando tambem um exantema, que evoluiu com aspéto nitidamente variceliforme e regrediu alguns dias depois.

\section{EXAMES COMPLEMENTARES}

27-12-40 - Pesquisa de S. cruzi no sangue a fresco - negativa.

5- 1-41 - Pesquisa de S. cruzi no sangue a fresco negativa.

10-1-41 - Pesquisa de S. cruzi no sangue a fresco positiva.

10- 1-41 - Pesquisa de $S$. cruzi em gota espessa - positiva .

24- 1-41 - Hematias - 4.560.000.

Leucocitos - 34.200.

Hemoglobina - 55\% (Sahli).

Valor globular - 0,61.

Xenodiagnostico - 4 larvas de $P$. megistus, examinadas em 13-3-1941 — todas infetadas.

OBSERVAÇÃO N.* 14

(Drs. Antonio Torres e Antonio Torres Sobrinho)

Jorge Miguel Elias, moreno, solteiro, 24 anos, lavrador, 
residente na fazenda Campo Alegre, próximo a Medeiros, município de Bambuí.

Teve moléstias da infancia (sarampo, etc.), nada mais acusando digno de nota. Nega contágio venereo e impaludismo.

Nasceu em Campo Belo, de onde saiu, com 4 anos de idade, para a cidade de Bambuí, onde permaneceu cerca de dois anos, tendo-se transferido posteriormente para o sitio onde atualmente reside.

Mora em casa rebocada e caiada, na qual têm sido encontrados "barbeiros".

Em. 7 de Janeiro de 1941 notou a presença de uma mancha avermelhada circular, de cerca de 1,5 centimetros de diametro na palpebra inferior direita. No dia seguinte sobreveiu edema da região, que se estendeu, alguns dias depois, à palpebra superior correspondente.

Esse edema, que chegou a determinar oclusão da fenda palpebral, acompanhou-se de prurido moderado e lacrimejamento. Cerca de uma semana após o aparecimento do edema, apresentou-se infartamento do gânglio pre-auricular direito. O doente acusou arrepios e febre moderada logo desde os primeiros dias, sendo que até os primeiros dias de Janeiro notou que também a pálpebra superior esquerda se achava edemaciaca.

Exame em 7-2-41: Apresenta edema pouco acentuado das palpebras direitas e da superior esquerda, que se apresentam um pouco avermelhadas. Gânglio preauricular direito ainda bastante crescido.

Ausencia de edemas em outros pontos.

Pulso -77 , ritmado. Temperatura $-36^{\circ}, 4$, à tarde.

Figado a 1 dedo abaixo do rebordo costal. Baço não paIpavel.

Nada digno de nota ao exame dos demais aparelhos.

\section{EXAMES COMPLEMENTARES}

5- 2-1941 Pesquisa de $S$. cruzi em gota espessa - positiva. 
Hematias - 7.140.000; leucócitos - 6.600; hemoglobina $-78 \%$ (Sahli); valor globul. $-0,55$.

Xenodiagnóstico -3 larvas de $P$. megistus .

Examinadas em 1-5-41, todas se mostraram infetádas.

7- 2-1941 Wassermann-Kolmer - negativo

7- 9-1941 Wassermann-Kolmer - negativo

Reação de Machado - positiva $(+++)$ (antígeno alcóolico de Romaña).

Barbeiros domiciliares examinados:

1 \% de $P$. megistus - positiva.

\section{OBSERVAÇÃO N." 15 \\ (Dr. Antonio Torres Sobrinho)}

- 28-3-1941 - Almerinda Teixeira Nunes, residente na fazenda do Cravo, distrito de Bambuí, 16 mezes de idade, branca. Mora em casa onde têm sido encontrados "barbeiros".

Antecedentes familiares e pessoais sem importância.

Há cerca de 20 dias lhe surgiu um edema e ligeira rubefação das pálpebras esquerdas e zona vizinha, seguido de febre, que se manteve alta uns 6 dias. Desde então os fenomenos inflamatórios locais e a reação geral foram-se atenuando, até chegar ao estado em que veiu à consulta.

Exame em 9-4-1941: Edema elástico, em regressão, das pálpebras esquerdas e circunjacências; ligeira reação conjuntival sem secreção; côr vermelho-arroxeada da região. Gânglio preauricular correspondente bem aumentado de volume, como também, em geral, quasi todos os gânglios habitualmente accessiveis à palpação. Figado e baço aumentados de volume; temperatura $37^{\circ}, 9$, à tarde.

Aparelhos circulatório, respiratório e digestivo, sem m.odificações que mereçam menção. 


\title{
EXAMES COMPLEMENTARES
}

9- 1-41 - Pesquisa de S. cruzi em gota espessa - positiva .

\author{
OBSERVAÇÃO N. ${ }^{\circ} 16$ \\ (Drs. Antonio Torres e Antonio Torres Sobrinho)
}

5-4-1941 - Zulmira Piedade da Silva, 5 anos e meio, residente na Fazenda da Glória (Lobeira ou Aguazinha). Mora em casa de tijolos, sem: reboco, de soalho de madeira e coberta de telhas, com muitos "barbeiros".

Tem 3 irmãos. Uma irmã mais velha (Maria, com 10 anos, surda-muda) já teve edema palpebral unilateral, com febre, ha cerca de 4 anos.

Adoeceu em 24-3-1941, com edema acentuado das pálpebras esquerdas, duro e de coloraçãc violacea, e hiperemia acentuada das conjuntivas. Esta hiperemia durou cerca de 3 a 4 dias.

Foi à consulta 8 dias após o inicio da moléstia, apresentando nessa ocasião, além do edema palpebral, febre e inapetência. A febre, a principio contínua, ultimamente se tem manifestado com maior intensidade à noite, segundo informa a familia da paciente.

Exame em 14-4-1941 - Sinais oculares ainda acentuados, notando-se tambem a ocorrência da dacrioadenite. Infiltração subcutânea generalizada, mais pronunciada na face, que se apresenta com aspéto "bouffi".

Gânglios submaxilares aumentados, principalmente à $e$ querda; preauricular esquerdo igualmente infartado; epitrocleanos grandes; microadenia inguinal. Figado a dois dedos abaix ${ }_{0}$ da reborda costal, na linha hemi-clavicular. Baço não explorável, devido ao timpanismo abdominal. Anorexia. Constippação e meteorismo do ventre.

Aparelho circulatório: eretismo; pulso ritmado, a 130 por 
minuto. Temperaturas tomadas à tarde, nos dias 11,12 e 14 de abril: $37,8-38,2$ e 37,2 .

Dia 17 de abril - Edema dos membros inferiores; edema palpebral tambem do lado direito, embora muito menos acentuado que no esquerdo (após 2 injeções - $7 \mathrm{cc}$. - de "Bayer 7.602”.) Prisão de ventre,inapetência. Sistema nervoso norma]

\section{EXAMES COMPLEMENTARES}

1- 4-41 - Pesquisa de $S$. cruzi em gota espessa - posiva.

12- 4-41 - Pesquisa de S. cruzi em gota espessa - positiva.

12- 4-41 - Xenodiagnóstico - 6 larvas de P. megistus. Examinadas em 13-6-41, mostram-se todas infetádas.

16- 4-41- Hematias - 4.070.000

Leucocitios - 4.800

Hem.globina - $73 \%$ (Sahli)

Valor globular - 0,91

Barbeiros domiciliares examinados:

1 ô, 1 \% e 6 larvas $P$. megistus - negativos.

3 ninfas de $T$. infestans - negativos.

\section{OBSERVAÇÃO N. ${ }^{\circ} 17$}

\section{(Dr. Elias Lasmar)}

14-4-1941 - Ana Maria de Jesus, sexo feminino, 3 anos e 8 meses, branca, residente na fazenda do Ingazeiro, distrito de Corrego d'Anta, Municipio de Luz.

Mora em cafúa coberta de sapé, com barbeiros em abundancia.

Nada de importância quanto aos antecedentes familiares e pessoais. Adoeceu no dia 14 de março, mais ou menos, con febre e dispnéa. A febre era mais elevada à noite. Apareceu em 
seguida edema duro e elástico localizado em todo o rosto. Nessa ocasião, apresentou também urticária generalizada (esquizotripanide urticariforme), cuja duração e data exata de aparesimento não foi possivel determinar.

Suspeitando-se inicialmente de malaria, foi-lihe receitado Paludan, do qual chegou a tomar apenas uma injeção.

Feitas preparações de sangue (esfregaços e gotas espessas) em 3-4-41, foram encontrados vários exemplares de Schiszotrypanum cruzi.

Examinada m 14-4-41, em Belo Horizonte, nada se observava digno de nota, a não ser ligeiro aumento do fígado. Baço não palpavel. Edema do rosto já desaparecido quasi completamente. Ventre crescido, timpânico, não doloroso. Gânglios submaxilares e inguinais pequenos.

Temperatura $37^{\circ}, 2$, à tarde. Pulso - 118 .

Nada a assinalar ao exame dos demais aparelhos.

\section{EXAMES COMPLEMENTARES}

3- 4-41 - Pesquisa de S. cruzi em gota espessa - positiva.

12- 4-41 - Xenodiagnóstico - 5 larvas de $P$. megistus. Examinadas em 11-6-41, 4 larvas mostraramse infetádas.

17- 4-41 - Hematias - 4.250.000. Leucocitos -8.800 . Hemogiobina - 68\% (Sahli) . Valor globular $-0,80$.

\section{OBSERVAÇÃO N.. ${ }^{\circ} 18$ \\ (Dr. Antonio Torres Sobrinho)}

22 - 4 - 1941 - Claudio Tancredo, 3 anos e 6 meses, residente à rua do Quartel, em Bambuí. Pai falecido ha 2 anos (morte subita) .

Residiu, até a idade de 1 ano, em casa rebocada, em que 
não havia barbeiros. Mudou-se depois para a habitação em que atualmente reside (casa não rebocada e coberta de capim), onde têm sido encontrados numerosos barbeiros.

Adoeceu ha cerca de 1 mês, tendo inicialmente aparecido um sinal de picada de inséto no ângulo palpebral interno do lado esquerdo; sobreveiu no dia seguinte edema bipalpebral do mesmo lado, com intensidade crescente, até determinar oclusão do olho, manifestando-se tambem secreção muco-purulenta e apresentando as palpebras uma coloração arroxeada. Estes sintomas oculares perduraram cerca de duas semanas, começando depois a regredir, de modo que atualmente se nota apenas ligeira infiltração da pálpebra inferior, que apresenta coloração normal.

Gânglio preauricular bastante aumentado do lado esquerdo e não perceptivel à direita. Gânglios epitrocleano, sub-maxilar, inguinais e axilares palpaveis.

Queixa-se de dôres abdominais e ao rivel dos membros. O rosto apresenta ainda certa tumefação, notando-se também discreta infiltração nos membros inferiores.

Aparelho respiratório: estertores de bronquite predominantes do lado aireito. Aparelho circulatório: pulso ritmado, 113 por minuto; desdobramento da 2 . $^{\text {bulha }}$.

Ventre crescido, não doloroso à palpação. Fígado com a borda inferior a 3 dedos abaixo da reborda costal. Baço não palpavel e de limites normais à percussão.

Temperatura, às 5 horas da tarde $-38^{\prime \prime}$.

\section{EXAMES COMPLEMENTARES}

10- 4-41-- Pesquisa de S. cruzi em gota espessa - positiva .

Xenodiagnostico -4 larvas de P. magistus . Examinadas em 22-5-41. Todas se mostraram infetádas .

25- 4-41 - Pesquisa de $S$. cruzi em gota espessa - positiva. 
Hematias - 4.615.000; leucocitos - 9.900, hemoglobina $-62 \%$ (Sahli); valor globular $-0,67$.

\section{OBSERVAÇÃO N. ${ }^{\circ} 19$}

(Dr. Antonio Pires Sobrinho)

22-4-1941 - Maria Aparecida de Jesus, 3 anos e 3 mêses, branca, residente em Pedrinha, próximo a Bambuí.

Antecedentes mórbidos sem importância. Nunca teve paIudismo.

Nada digno de nota quanto aos antecedentes familiares.

Mora em cafúa coberta de capim e sem rebôco, onde tem sido verificada a presença de numerosos barbeiros.

Adoeceu ha 15 dias, com febre e inchação no olho direito. A febre sobrevem geralmente à noite. Posteriormente se manifestou infiltração subcutânea no rosto, que se apresenta um pouco tumefeito. Nestes últimos dias a infiltração apareceu com mais intensidade nos membros inferiores. Temperatura às 4 horas: 37,7 . Pulso: 126.

Gânglios: inguinais e axilares, crescidos; preauriculares e epitrocleanos náo perceptiveis.

Pulso ritmado, 126 por minuto. Reforço do $2 .^{\circ}$ tom pulmonar. Fígado a 3 dedos abaixo do rebordo, na linha hemiclavicular. Baço a 2 dedos do rebordo costal esquerdo.

\section{EXAME OFTALMOLOGICO}

Olho direito - edema palpebral superior e inferior de média intensidade, mole e indolor ao táto ; rima palpebral reduzida à metade; secreção. Não se nota local de picada. Conjuntiva bulbar de aspecto normal. Motilidade ocular normal, assim comino reação à luz e à acomodação. Glandula lacrimal normal.

(Dr.B. Furtado Gomes) 


\section{EXAMES COMPLEMENTARES}

22-4-41 - Pesquisa de S. cruzi em gota espessa - positiva.

26-4-41 - Hematias - 4.040.000

Leucocitos - 6.600

Barbeiros domiciliares:

2 c. de $P$. megistus - positivos

$1 \mathrm{~L}$ de $P$. megistus - negativa

OBSERVAÇÃO N. 20

(Dr. Ananias A. Teixeira)

1-11-1940 - "Ficha 1871 de 1-11-1940" (Rio Paranaiba Minas Gerais). Cananéa - 10 anos, branca, nascida e residente em Olhos d'Agua de São João, distrito de Araguá, municipio de Rio Paranaíba.

Ha cerca de uns 12 dias, ihe apareceu forte edema em ambas as palpebras do olho esquerdo. Não se queixou de dôr desde o inicio. Menina de desenvolvimento normal; mediolínea; pele ligeiramente resecada; estado geral bom.

Gânglio preauricular esquerdo do tamanho de um grão de milho; nada para o lado da boca, do nariz e do ouvido; conjuntivas oculares normais. Temperatura 38,5 e 138 pulsações por minuto. Ao exame geral, nada mais revela de interesse.

Evolução do caso: Lembrada a possibilidade de estar diante de um caso agúdo da Moléstia de Chagas, recomendei que a doente me fosse levada ao consultório, em S. Gotardo.

Só a 15 de dezembro conseguí ver de novo a dnente. Estava com 37,5 e 126 pulsações. Edema e ganglio diminuidos. A doente recusou submeter-se à colheita de sangue. Foi fotografada. Pedí que me fossem enviados alguns "barbeiros" da casa, de cuja existencia havia me assegurado já na primeira consulta

Em 30 de dezembro esteve no consultorio, com 38,0 de terperatura e 120 pulsações, tendo edemas e gânglio quasi desaparecido. Colheram-se esfregaços de sangue. 
peratura e 126 pulsações, sem edema e sem reação ganglionar. Xenodiagnostico.

\section{EXAMES COMPLEMENTARES}

30-12-1940 Pesquisa do S. cruzi em esfregaços de sangue - positiva (Dr. Bento Ferreira dos Santos).

11-12-1941 Xenodiagnostico - 5 larvas de $P$. megistus - Examinadas em 27-3-41 — 4 larvas infetádas.

Barbeiros domiciliares:

$1 \mathrm{~N}$ de $\mathrm{P}$. megistus - Positiva

Xenodiagnostico em pessoas da familia:

João - 35 anos - negativo

Alderico - 12 anos - positivo.

\section{OBSERVAÇÃO N. ${ }^{\circ} 21$}

\section{(Dr. Antonio Torres)}

1-9-1941 - João Batista Caetano, brasileiro, de 15 anos, pardo, solteiro, lavrador, residente em Medeiros, municipio de Bambuí.

Nada digno de nota quanto aos antecedentes familiares. Teve sarampo aos dois anos.

Reside em casa cujas paredes são revestidas de rebôco e caiadas; piso de terra batida e cobertura de telhas. Ha barbeiros em sua residencia.

Doença iniciada ha cerca de 30 dias, ocasião em que notou uma elevação avermelhada e um pouco pruriginosa ao nivel do terço médio da face anterior do antebraço esquerdo. Dois dias depois sobrevieram hipertemia, arrepios e dôr nos membros inferiores. A febre, que apresentava elevações noturnas, vem. desaparecendo ultimamente. Ha cerca de uma semana, apareceu um edema duro dos membros inferiores, mais pronunciado dos joelhos para baixo, o qual ainda persiste.

Exame em 2-0-41 - Mucosas um tanto descoradas, gan- 
glios epitrocleanos, axilares esquerdos, submaxilares direitos e inguinais palpaveis. Um dos ganglios axilares esquerdos apresenta-se doloroso e bastante crescido. Presença do tumor já assinalado na face anterior do antebraço esquerdo.

Pulso a 128; ligeiro abafamento da $1 .^{n}$ bulha e hiperfonese do tom aórtico. Figado a 2 dedos abaixo da reborda costal, na linha hemiclavicular. Baço palpavel e percutivel a dois dedos do rebordo. Temperatura às 15 horas $-36,9$.

Pressão Mx - 10,25 Mn - 5.

Nada digno de nota ao exame dos demais aparelhos.

Diagnostico: Chagoma de inoculação na face anterior do antebraço esquerdo,terço médio. Adenites na região axilar: querda.

Em 3-9-41, foi feita exerese do chagoma, pelo Dr. Osvaldo Borges da Costa, no Instituto de Radium, onde estava internado o doente, por gentileza do Prof. Borges da Costa. No dia seguinte se praticou a retirada dos ganglios da axila esquerda.

\section{EXAMES COMPLEMENTARES}

29- 8-41 - Pesquisa do Scrizotrypanum Cruzi no sangue a fresco - positiva.

3- 9-41 - Hematias - 4.350.000 Leucocitos - 6.600

12- 9-41 - Ex. de urina - nada de anormal.

Exame histo-patologico efetuado pelo Prof. Otávio Magalhães :

O exame microscopico revelou uma verdadeira pandermite. Em alguns pontos, espessamento do epitelio malpighiano, que não se achava infiltrado. Espaços interpapilares ligeiramente infiltrados. Dominam nas preparações as formações nodulares giganto-histiocitarias, ora espaçadas, ora proximas umas das outras e de tamanho vário.

Vêem-se nesses nodulos celulas gigantes, epitelioides, proliferação histiocitaria intensa, alguns "Plasmazellen", linfocitos, monocitos e alguns polimorfonucleares. O tecido gorduroso 
sub-cutaneo está invadido por faixas de infiltração ou, em: al'guns pontos, verdadeiro lençol de infiltração, acompanhado de numerosos fibroblastas com necrose e substituição do tecido gorduroso. Em alguns pontos, principalmente nestes de necrose, ha equivalencia dos elementos polimorfonucleares e monocitarios. Em outros pontos dos espaços sub-epidermicos ha infiltração perivascular nitida.

Alta melhorado no dia 16-9-1941.

OBSERVAÇÃO N. ${ }^{\circ} 22$

(Dr. Elias Lasmar)

19-10-1941 - Maria Aparecida Passos, branca, 7 anos, residente em "Perdição", a 10 quilômetros da cidade de Bambuí. Mora em casa coberta de telhas e sem rebôco, onde têm sido encontrados barbeiros.

Antecedentes mórbidos sem importância no caso .

A doença iniciou-se ha cerca de 20 dias, com edema bipalpebral esquerdo, acompanhado de secreção conjuntival; febre com elevaçc̃es vesperais, anorexıa, prostração e dôres nas pernas.

Estado atual - (22-10-1941) Edema ainda bastante acentuado das palpebras esquerdas, não se notando sinais de dacrioadenite nem dacrioscistite. Hiperemia conjuntival de ambos os lados, mais acusada à esquerda. Gânglios preauriculares bem palpàveis, notadamente à esquerda; infarto pronunciado dos sub-maxilares esquerdos; aumento dos axilares, inguinais e do epitrocleano direito. Face ligeiramente infiltrada. Edema duro bastante acentuado dos membros inferiores. Fígado a 2 dedos abaixo da reborda cosíal. A doente não permitiu a palpação do baço, que, aliás, não se mostra aumentado à percussão.

Pulso: 140. Temperatura $-37^{\circ}, 2$ à tarde. Nada digno de nota ao exame dos demais órgãos. 


\section{EXAMES COMPLEMENTARES}

10-10-41 - Pesquisa do $S$. cruzi no sangue a fresco positiva.

Eletrocardiograma - nada de anormal

Barbeiros domiciliares examinados:

3 ô, 3 o e 1 larva de $P$. megistus - positivos.

2 larvas de $P$. megistus - negativos.

Tratamento: $58 \mathrm{cc}$. de sol. a $3 \%$ do preparado "Bayer 7.602" (Ac.) entre os dias 22-10 e 13-11-1941.

\section{OBSERVAÇÃO N.・ 23}

\section{(Dr. Antonio Torres Sobrinho)}

Sebastião Alves da Silva, 2 anos e 21 dias, moreno claro, residente na Fazenda de Olhos d'Agua, Municipio de Bambuí. Mora em cafúa em que ha barbeiros.

Antecedentes hereditarios e pessoais sem importância.

A doença atual iniciou-se ha cerca de um mês e 5 dias, com edema das palpebras, febre, erupção morbiliforme na face e nos membros, pronunciada diarrhéa. A erupção durou cerca de oito dias. Surgiram tambem, em seguida, edema generalisado, mais perceptivel nos pés, e ligeira tosse seca.

0 exame revela a existencia de edema bipalpebral acentuado no olho esquerdo, discreto no direito, bem como edema pouco perceptivel no tronco e membros superiores, mais acusado nos membros inferiores. Trata-se de edema elastico, que não deixa godet à presão. Ganglios preauricular esquerdo e inguinais volumosos, cervicais e epitrocleanos palpaveis e pequenos. Figado e baço aumentados de volume. Os demais orgãos nada apresentam de importante ao exame clinico. Colorido normal da face. Temperatura às 11 horas — $37^{\circ}, 9$. O pulso não foi registrado.

22-10-41 - Pesquisa de S. cruzi no sangue, a fresco positiva . 


\section{OBSERVAÇ̃̃O N. ${ }^{\circ} 24$ \\ (Dr. Antonio Torres Sobrinho)}

30-10-1941 - Osvaldo Ferreira, 9 anos, moreno-claro, residente na Fazenda da Gloria, local denominado Três Barras, Municipio de Bambuí. Mora em cafúa em que se encontram abundantes barbeiros.

Antecedentes hereditarios e pessoais sem importancia.

Ha cerca de 12 dias se iniciou a doença atual, com inflamação dos olhos (sic), seguida de febre, edema generalizalo, desanimo, sonolencia e inapetencia.

Ao exame apresenta edema elastico generalisado, particularmente acentuado nas palpebras esquerdas, discreto nas direitas, mais aparente nos membros inferiores. Ligeira rubefação palpebral e sub-palpebral esquerda. Gânglio preauricular esquerdo bem turgido, cervicais, submaxilares, epitrocleanos e inguinais aumentados de volume. Fígado e baço com as bordas anteriores palpaveis, três dedos abaixo das rebordas costais.

Temperatura às 11 horas - 37,6 - Pulso - 108 .

Os demais orgãos e aparelhos, sem: sinais clinicos que mereçam menção.

\section{OBSERVAÇÃO N. ${ }^{\circ} 25$ \\ (Dr. Elias Lasmar)}

19-12-1941 - Jesus de Oliveira, 5 anos, côr preta, residente em "Mata do Minguta", municipio de Bambuí. Mora em casa de "pau a pique", sem reboco, onde ha barbeiros en. grande quantidade.

Alguns dias anteriormente à doença da criança, foram encontrados barbeiros cheios de sangue em sua cama.

Antecedentes familiares sem importancia.

Doenças anteriores: sarampo e coqueluche. 
A doença iniciou-se com febre alta, sobrevindo depois edema dos membros inferiores.

Exame em 19-12-1941 - Edema duro dos membros inferiores; fígado a cerca de 3 dedos transversos da reborda costal; baço ligeiramente aumentado; temperatura: 39,5.

\section{EXAMES COMPLEMENTARES}

19-12-41 - Pesquisa do S. cruzi em gota espessa positiva. 


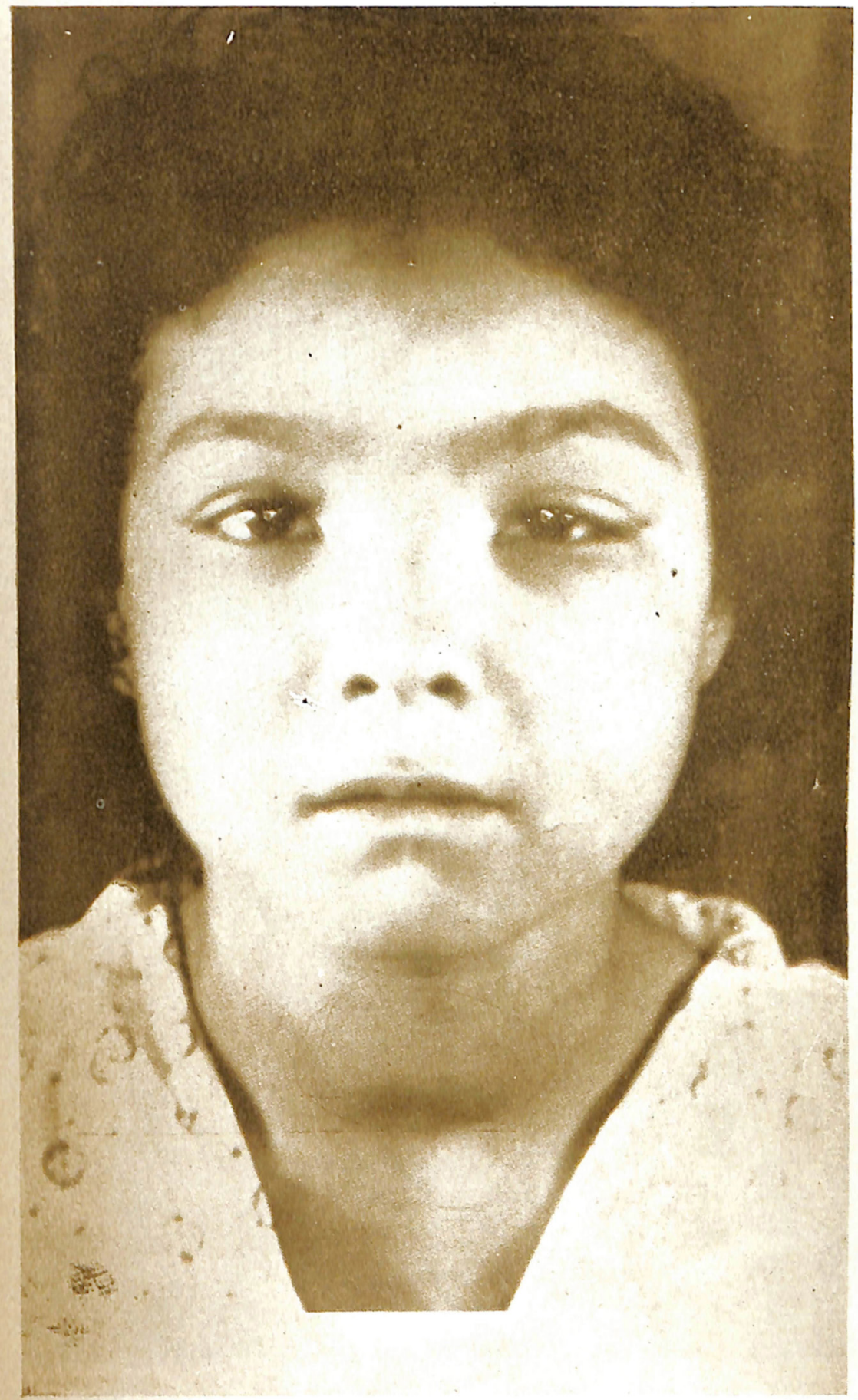

FIG. 1 - Maria Albina da Silva - Obs. n. ${ }^{\circ}$ - Fot. em 9 de outubro de 1940 - Note-se o edema palpebral do lado esquerdo, o edema do rosto e a hipertiofia da tiroide 


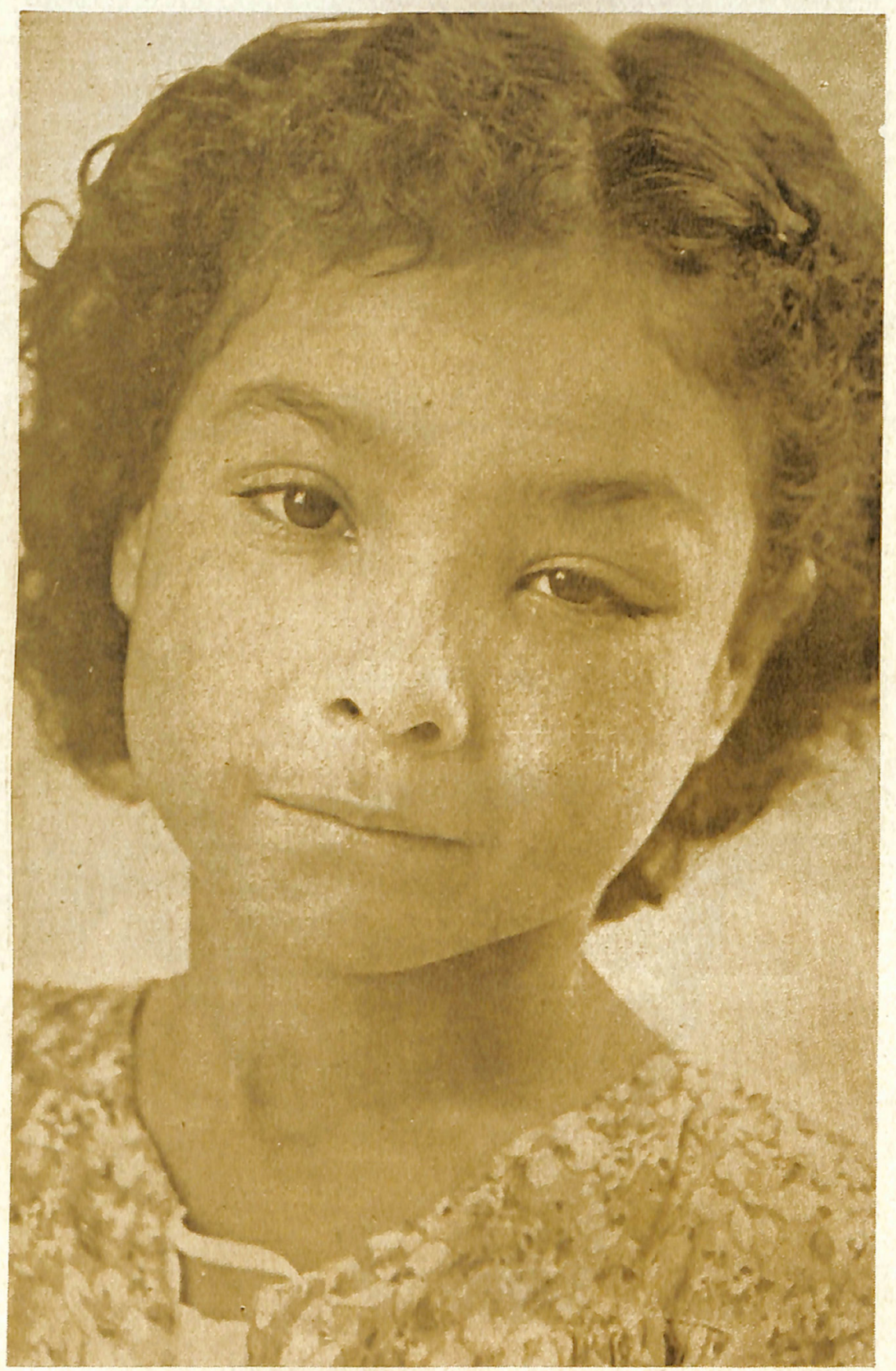

FIG, 2 - Maria Albina da Silva - Obs, n.03 - Fot, em 16 de novembro de 1940 - Note-se a fenda palpebral esquerda em forma de S'., a diminuição accntuada da hipertrofia da tiroide e desaparecimento do edema do rosto 


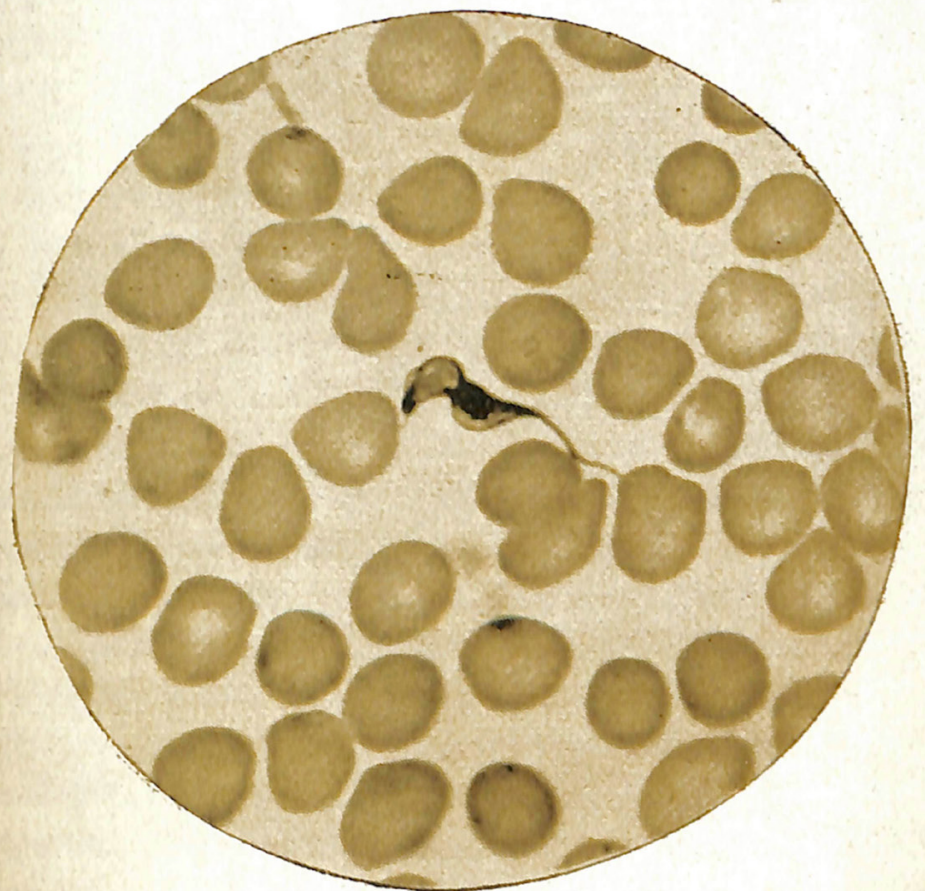

FIG. 3-Schizolryponum Cruzi - Esfregaço de sangue de Maria Albina da Silva - Obs, n. ${ }^{\circ} 3$ - 14 de outubro de 1940 Col. May-Grunwald-Giemsa 


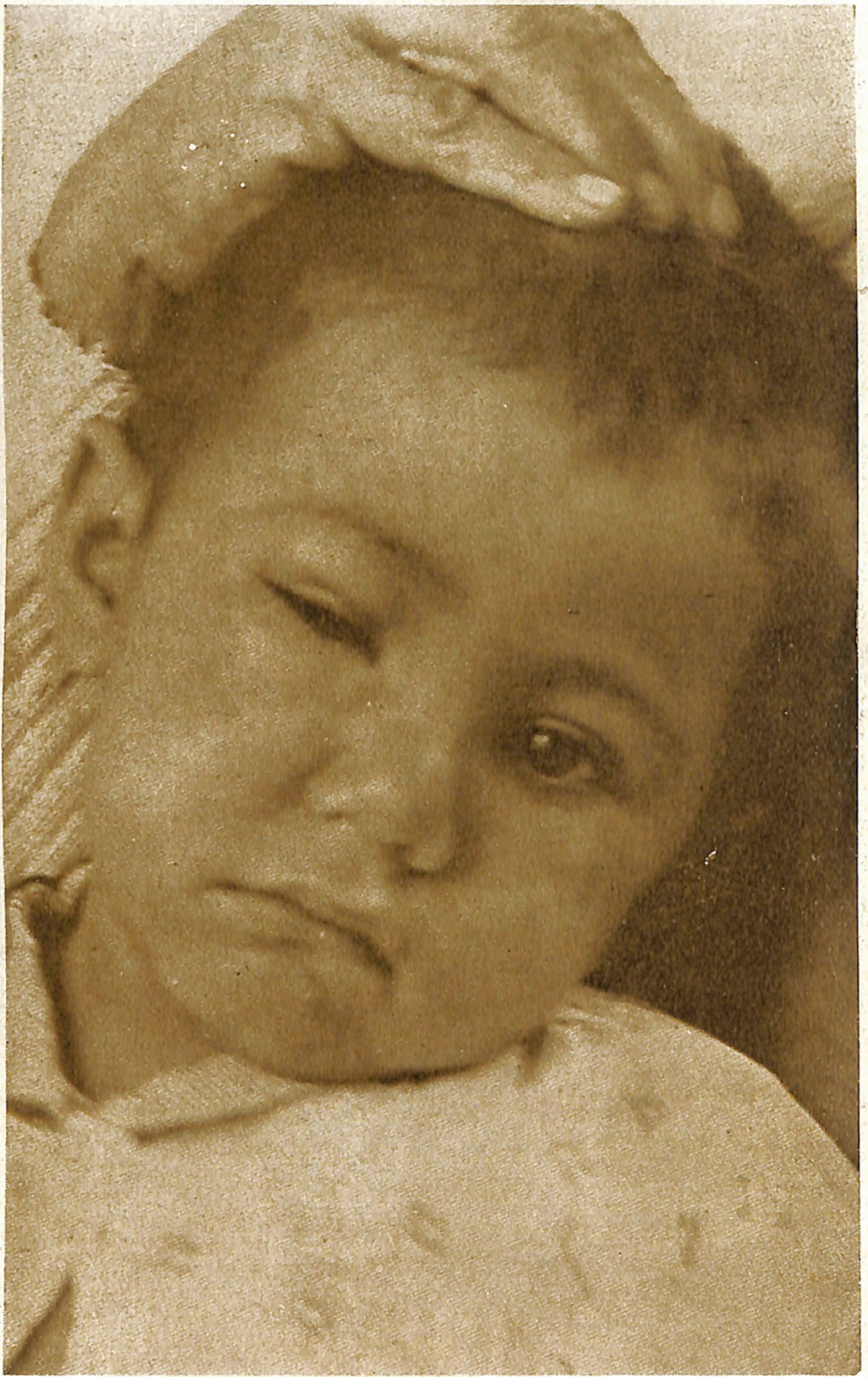

FIG. 4 - José Barbosa - Obs. n. ${ }^{\circ} 5$ - Fot. em 23-10-40 Sinal de Romana. 


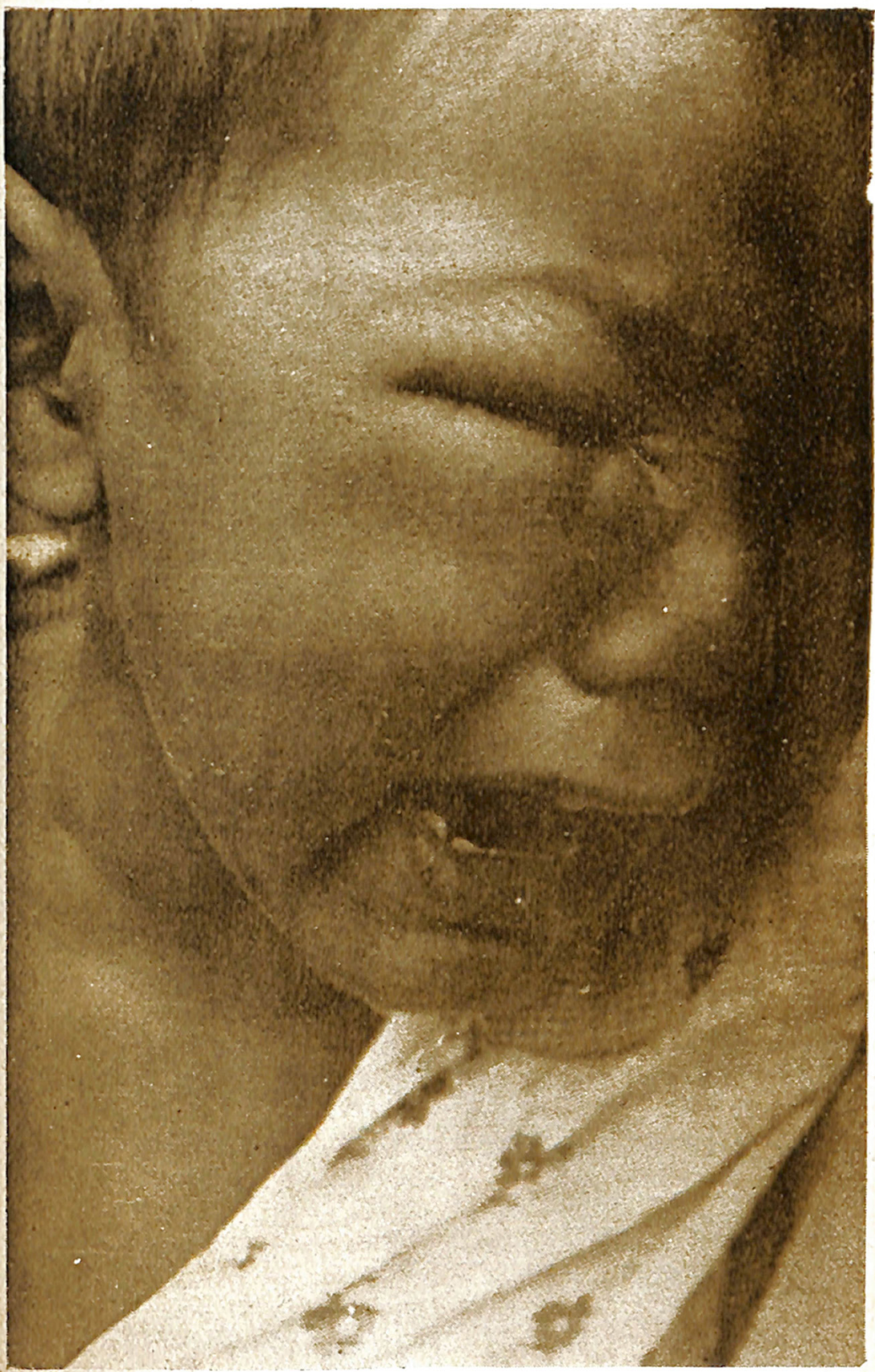

FIG. 5 - José Barbosa - Obs. n. 5 - Fot. em $23-10-4 \mathrm{C}$

Sinal de Romana. 


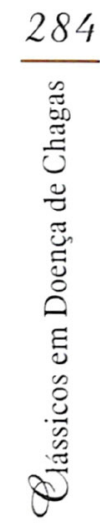

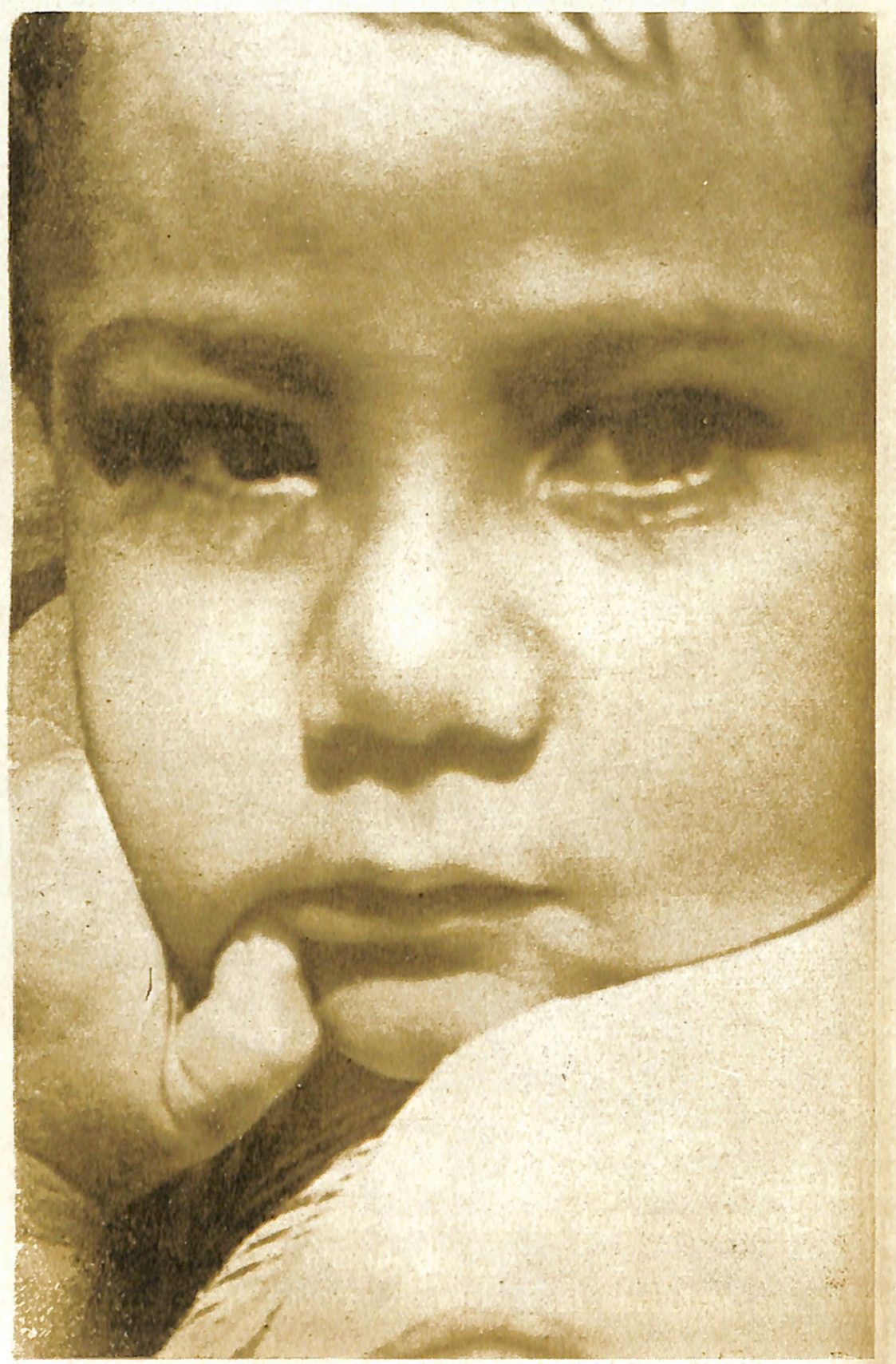

FIG. 6 - José Barbosa - Obs. n. ${ }^{\circ} 5$ - Fot. em 16-11-40 


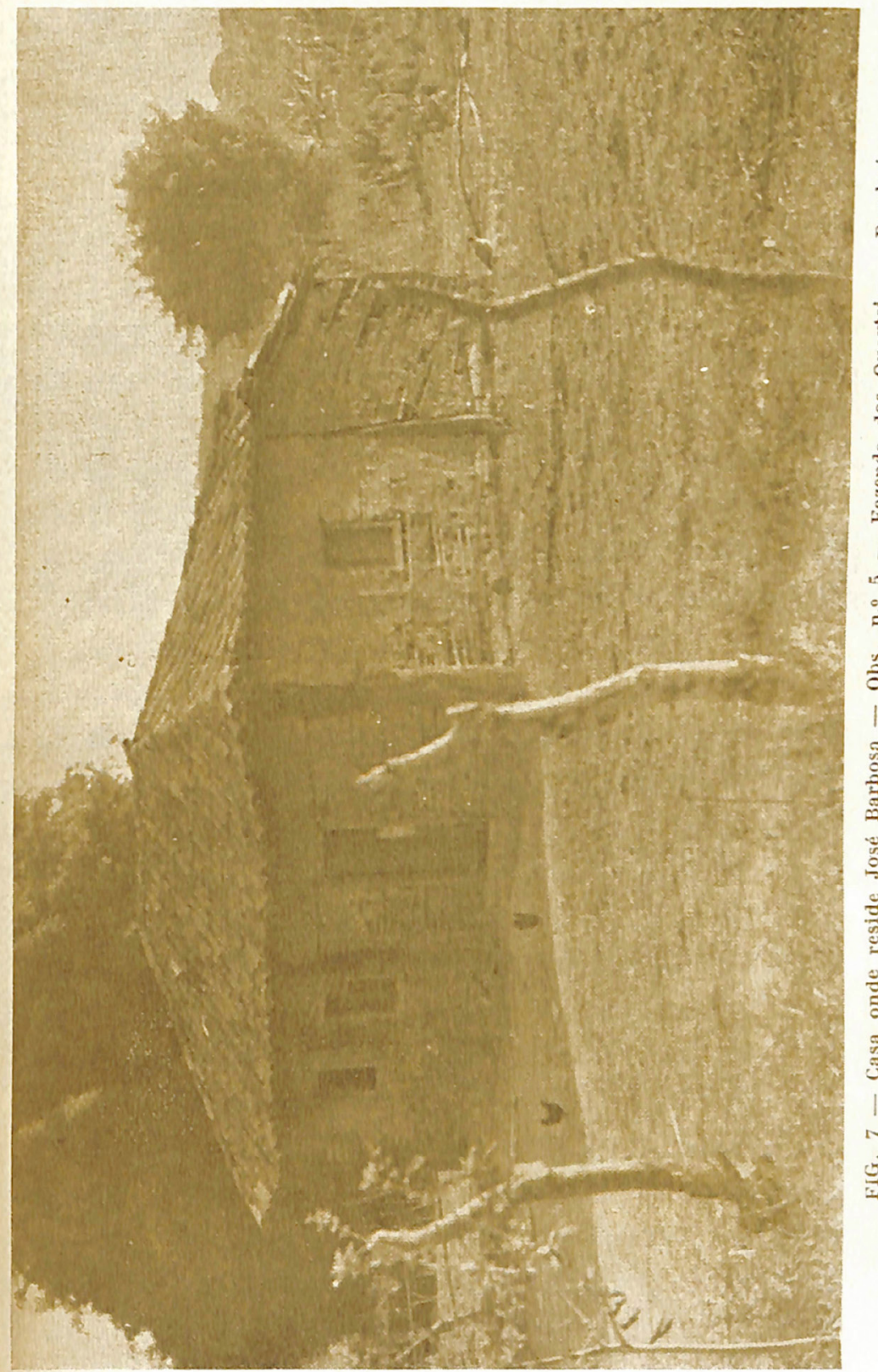




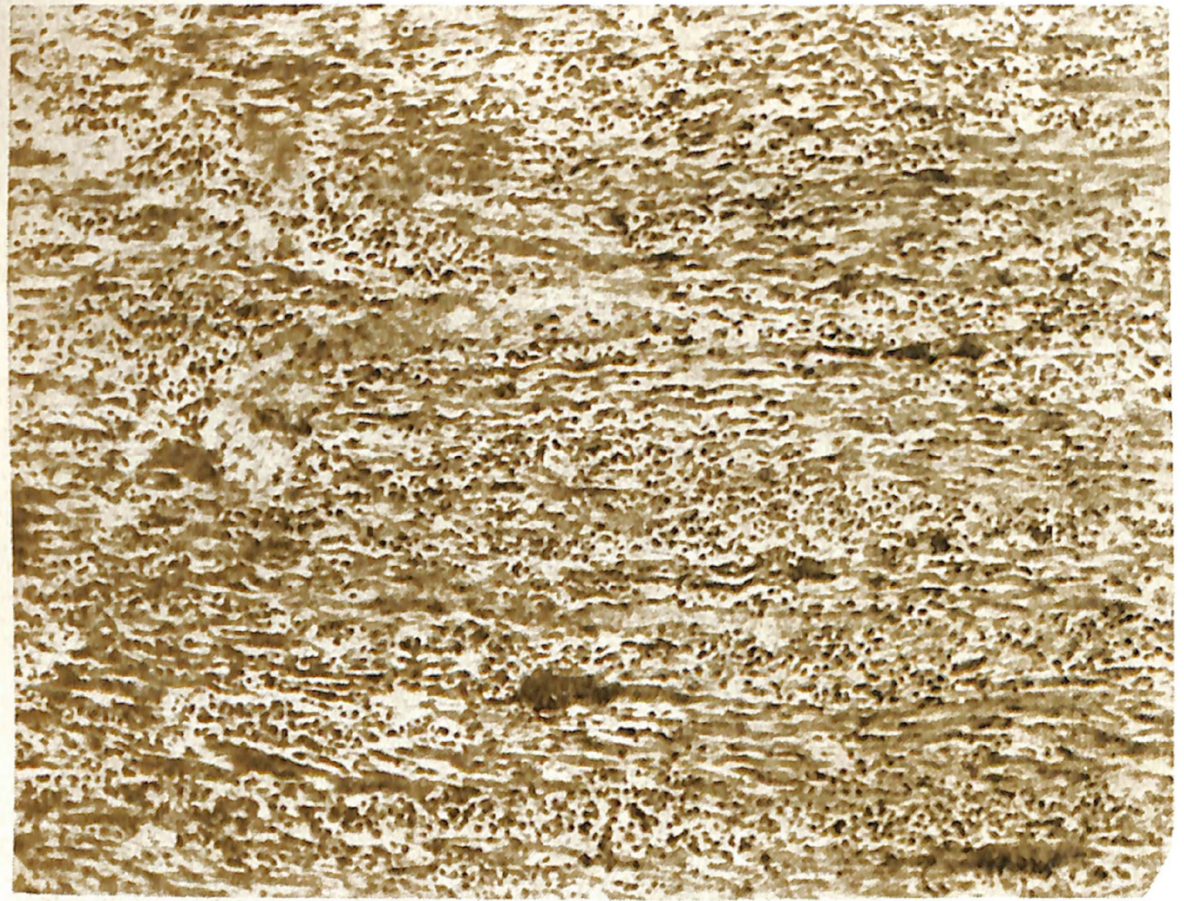

FIG. 8 - Corte de miocardio de Geralda Mota - Obs, n. ${ }^{\circ} 6$

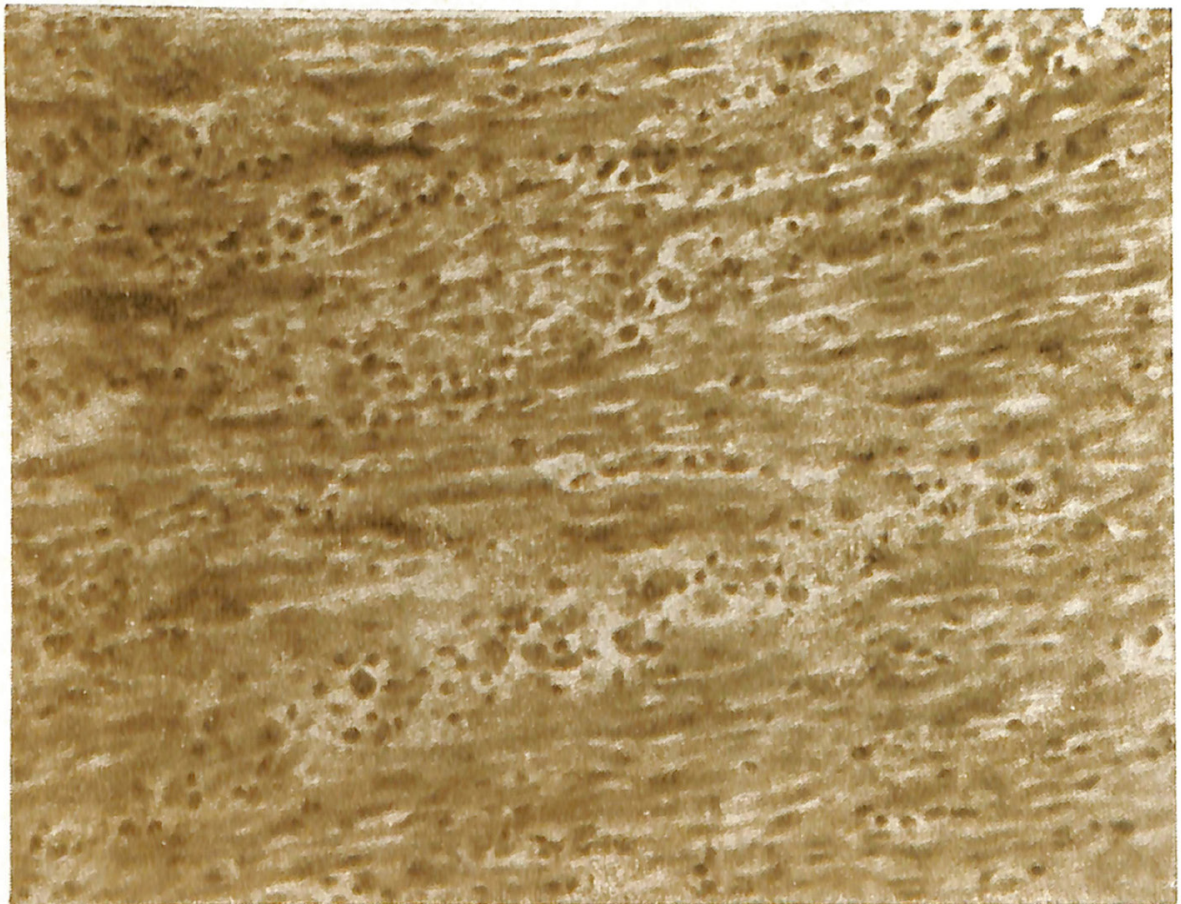

Fif 9 - Corle de miocardio de Geralda Niota - Obs. n. 6 


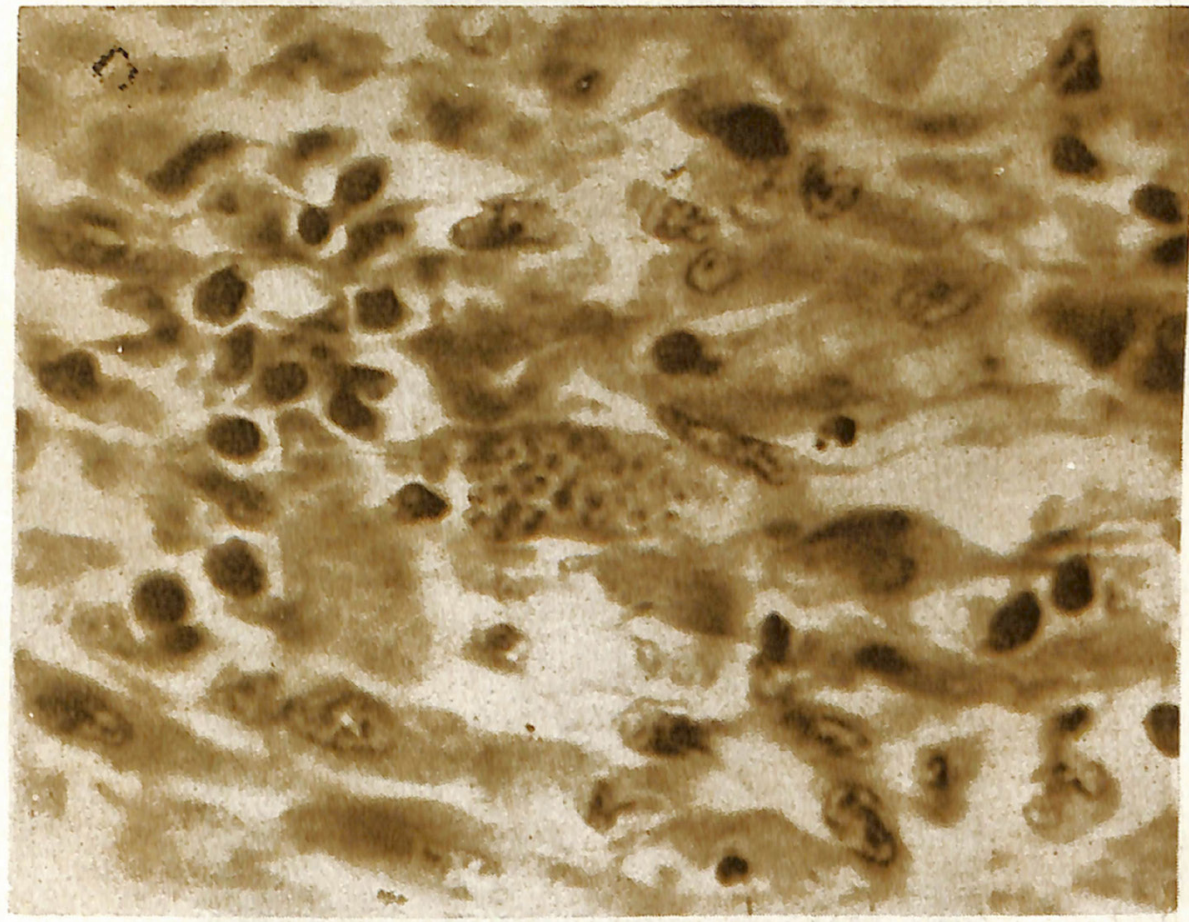

Fig. 10 - Córte de miocardie de Geraldo Mota - obs. n. 6. Formas leishmania do Schizotryparum cruzi. 


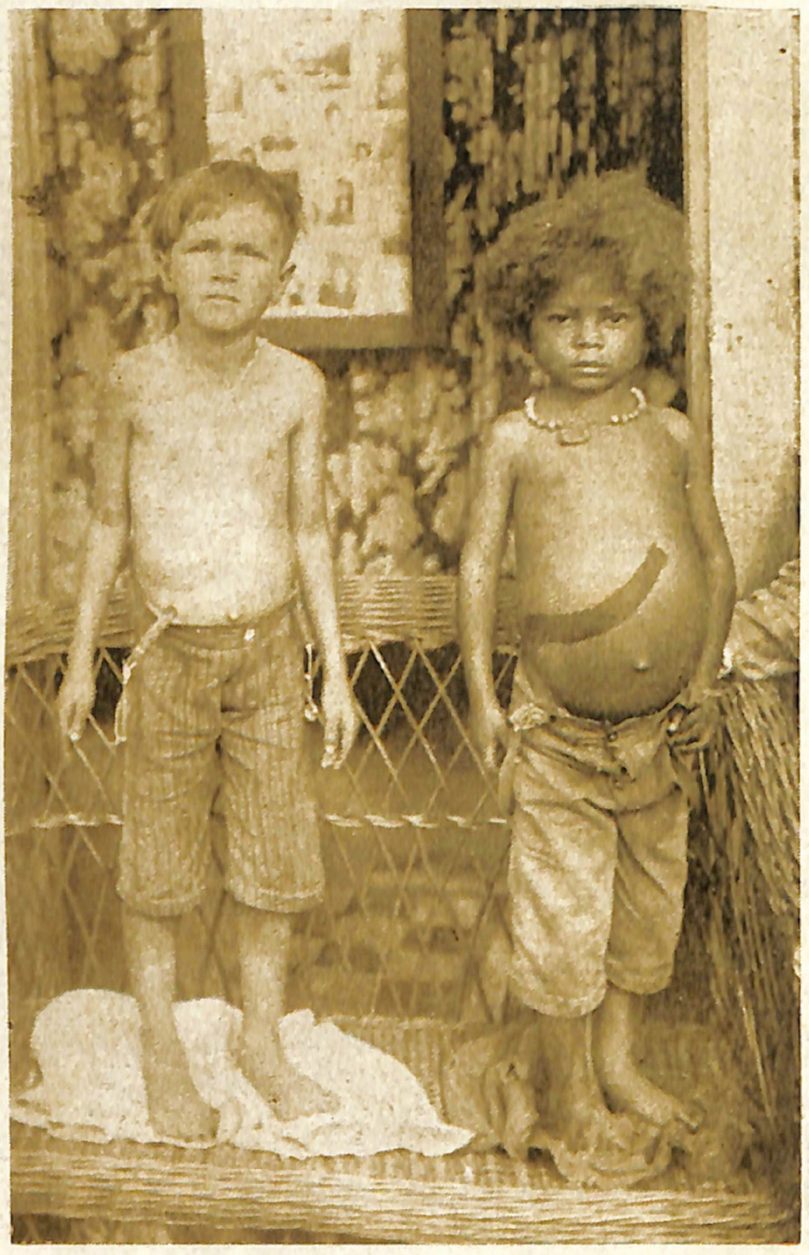

Fig. 11 - Vicente Pedro Gomes - Obs. n. 10, à direita e Juvenal P. Alves da Silva - Obs. n. 12, à esquerda. Fot. em 8-1-41. 


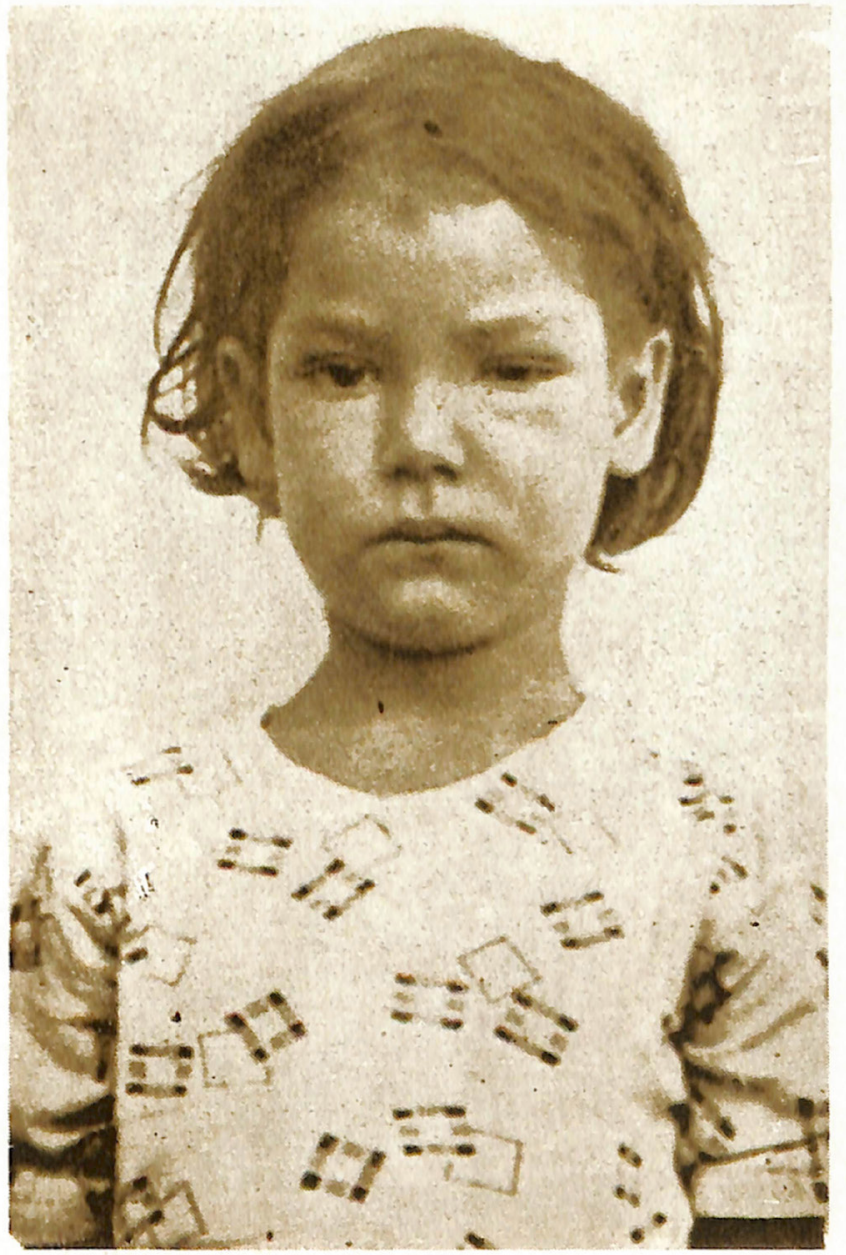

Fig. 12 - Zulmira Piedade da Silva - Obs. n. 16 . Fot. em 14-4-41. - Sinal de Romana. 


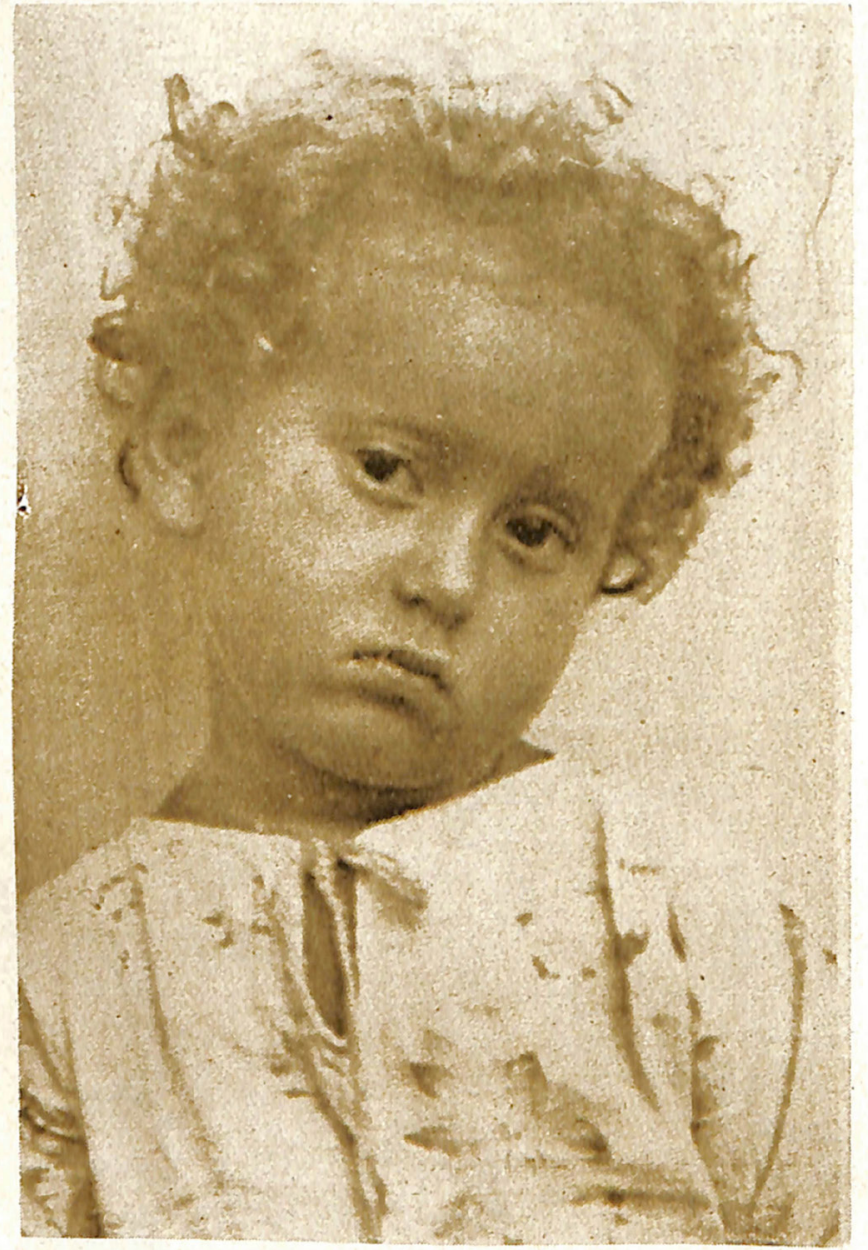

Fig. 13 - Ana Maria de Jesus - Obs. n. 17. Fot. em 14-4-41 


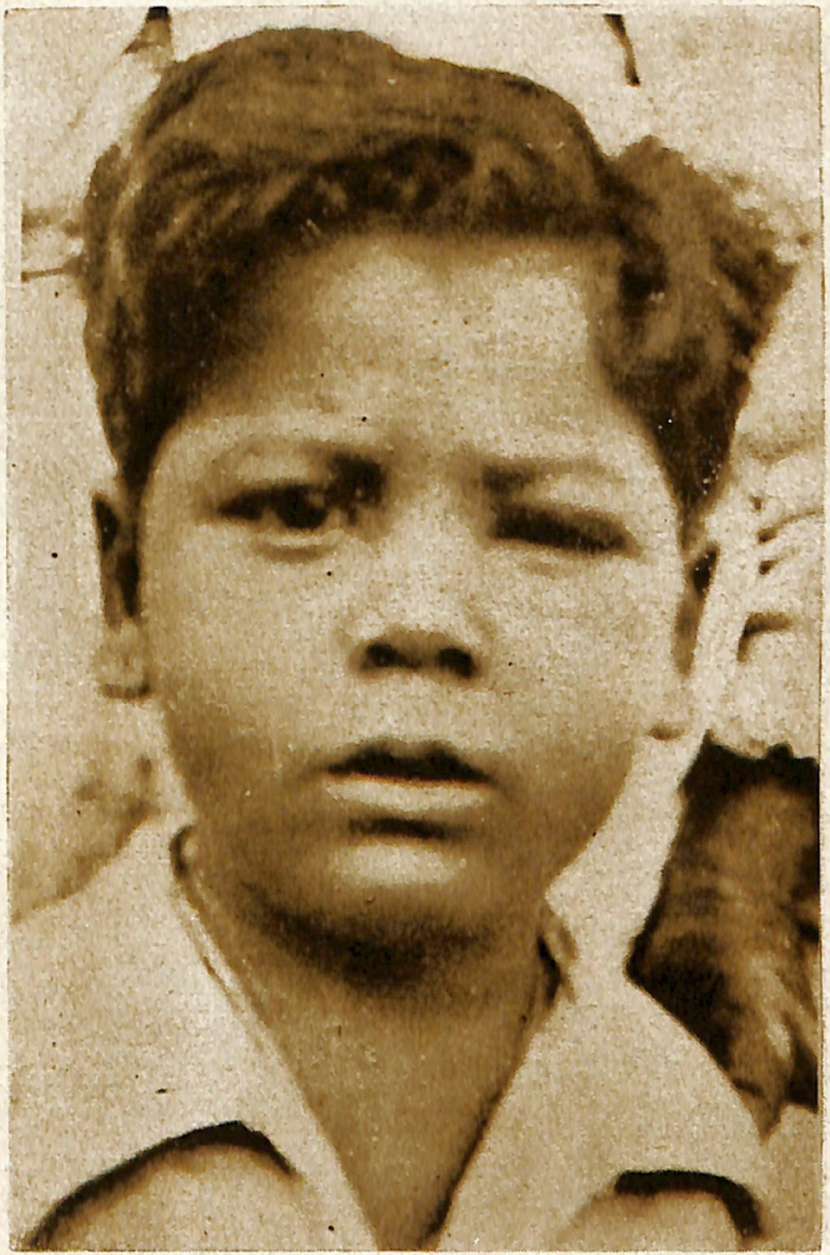

Fig. 14- Claudio Tancredo - Obs. n. 18. Fot. em 22-4-41. Sinal de Romana. 


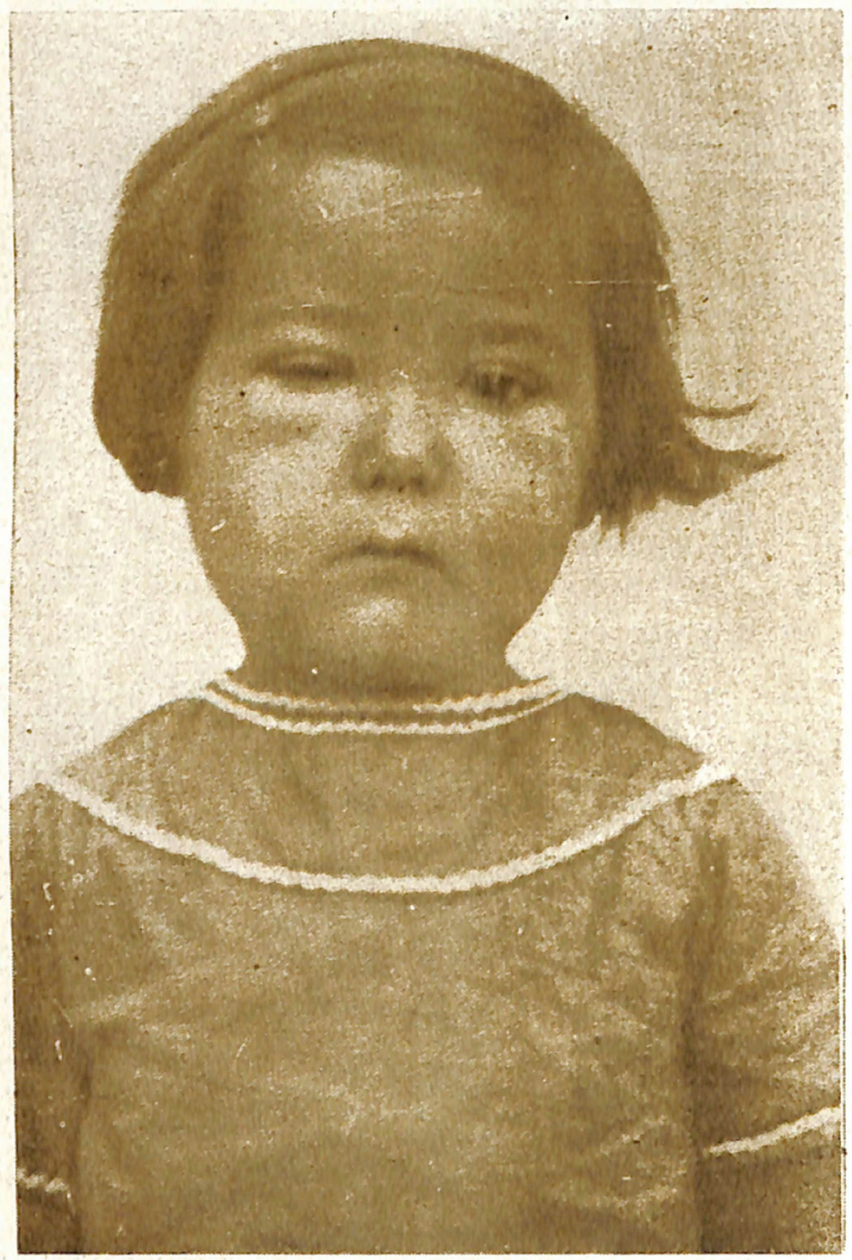

Fig. 15 - Maria Aparecida de Jesus - Obs. n. 19 - Fot. em 22-4-41. Sinal de Romana. 


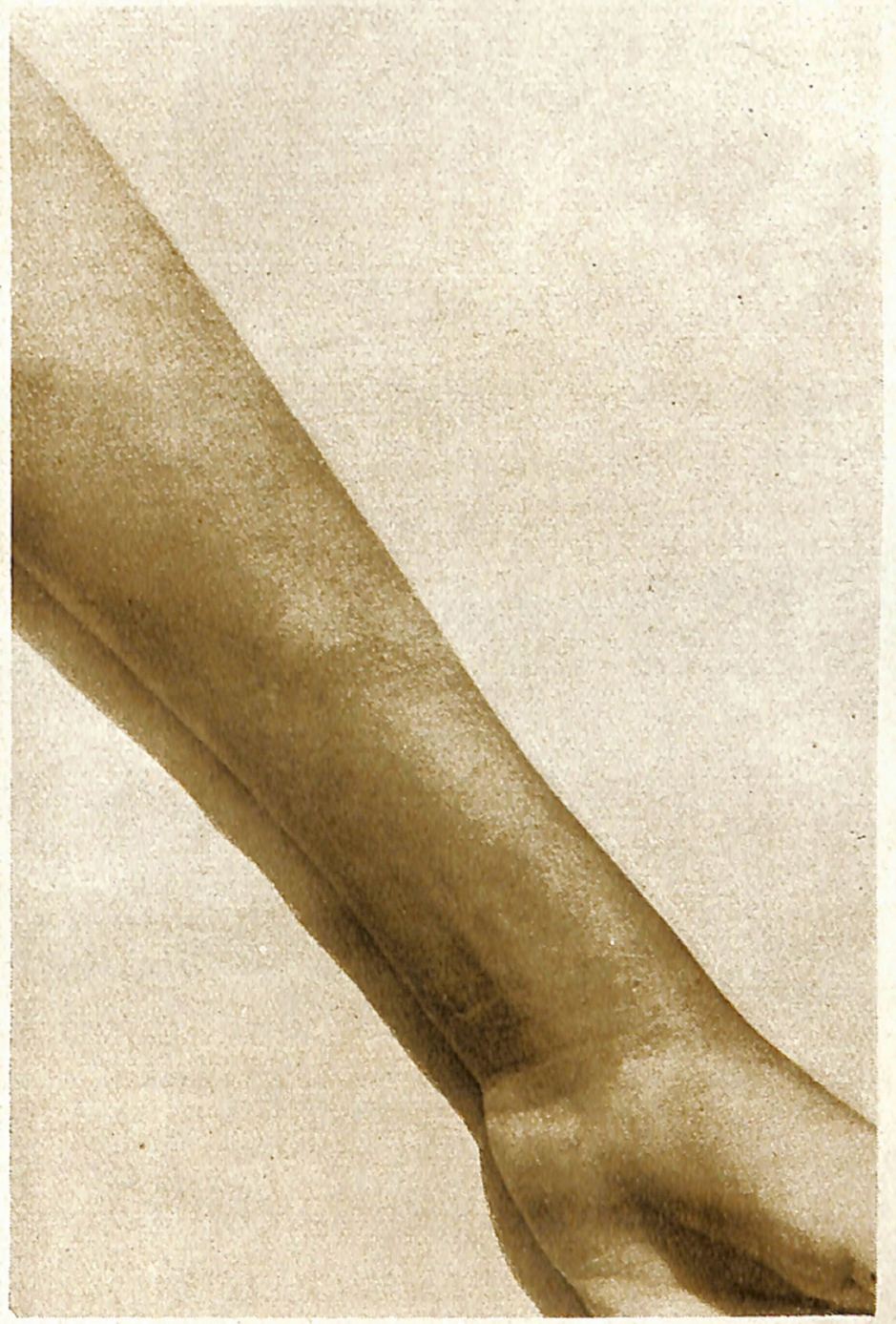

Fig. 16 - João Batista Caetano - Obs. n. 21 - Chagoma do antebraço esquerdo. - Fot. em 2-9-41. 


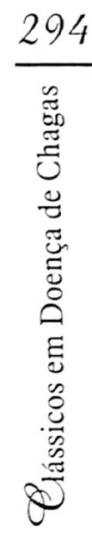

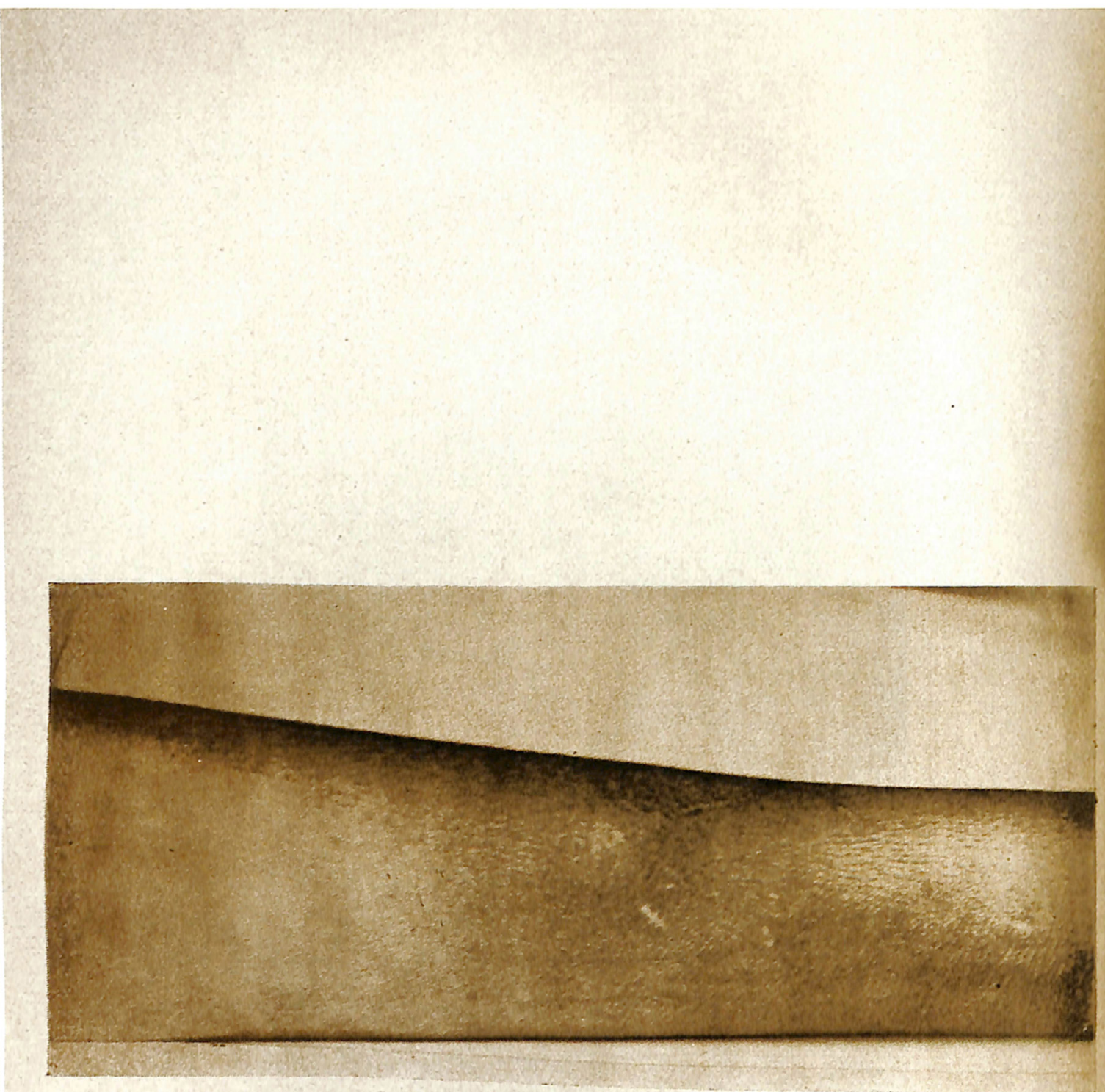

Fig. 17 - João Batista Caetano - Obs. n. 21 - Chagoma do ante- 


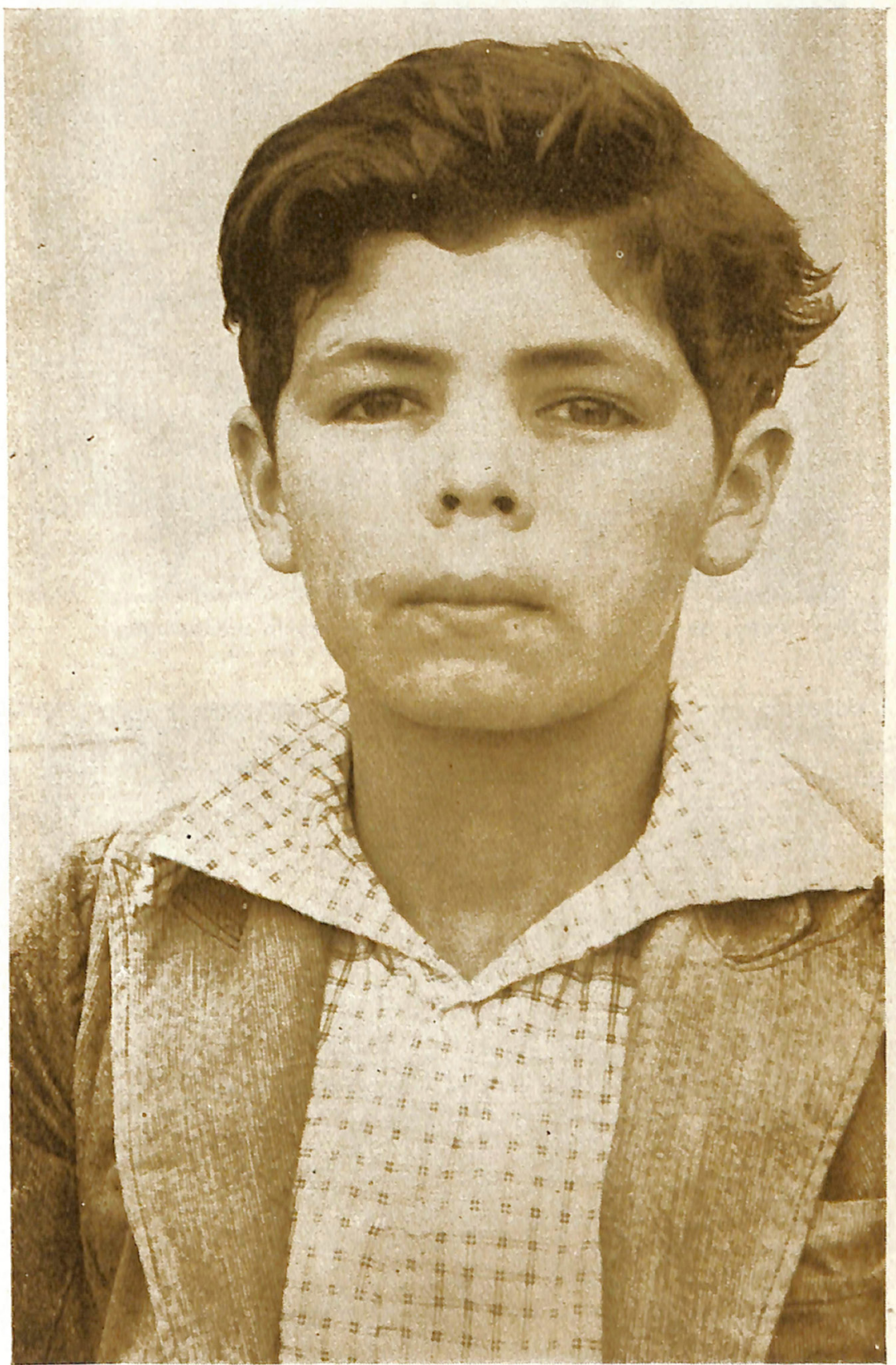

Fig. 18 - João Batista Caetano - Obs. .21 - Fot. em 2-9-41. 


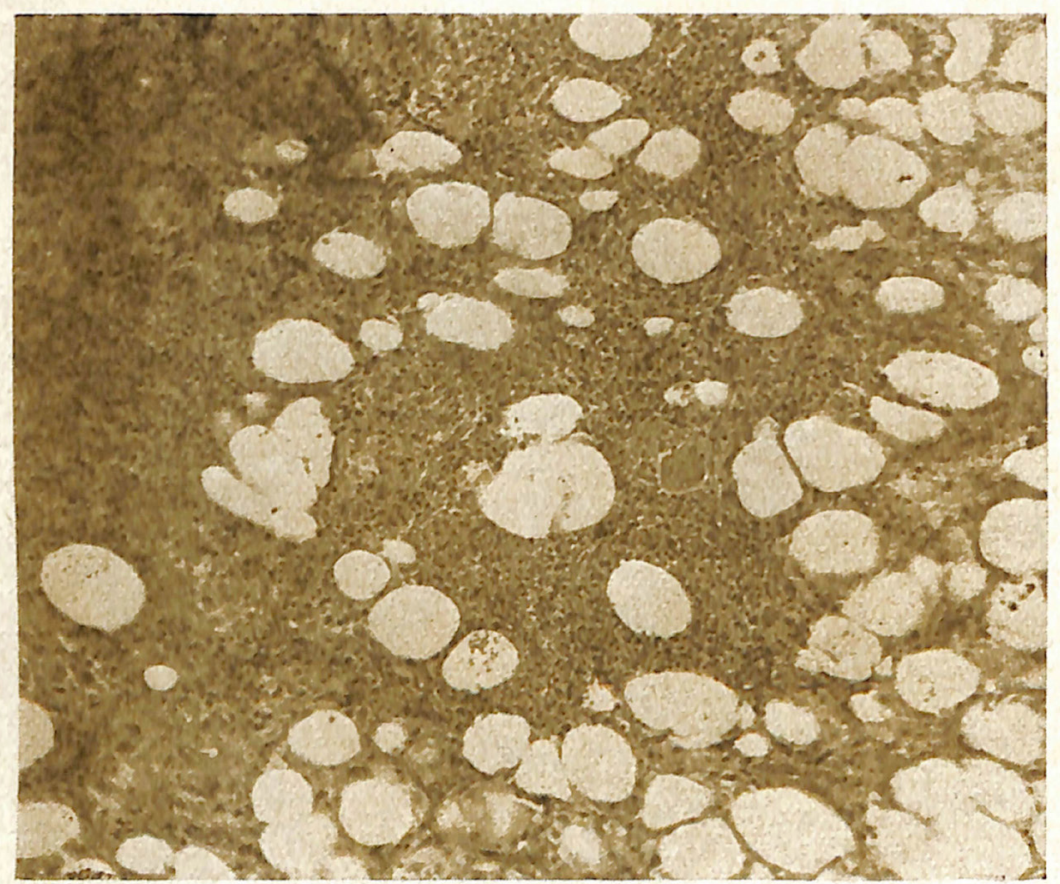

FIG. 19 - Chagoma de inoculação - aspéto microscopico. João Batista Caetano - Obs. n.o 21

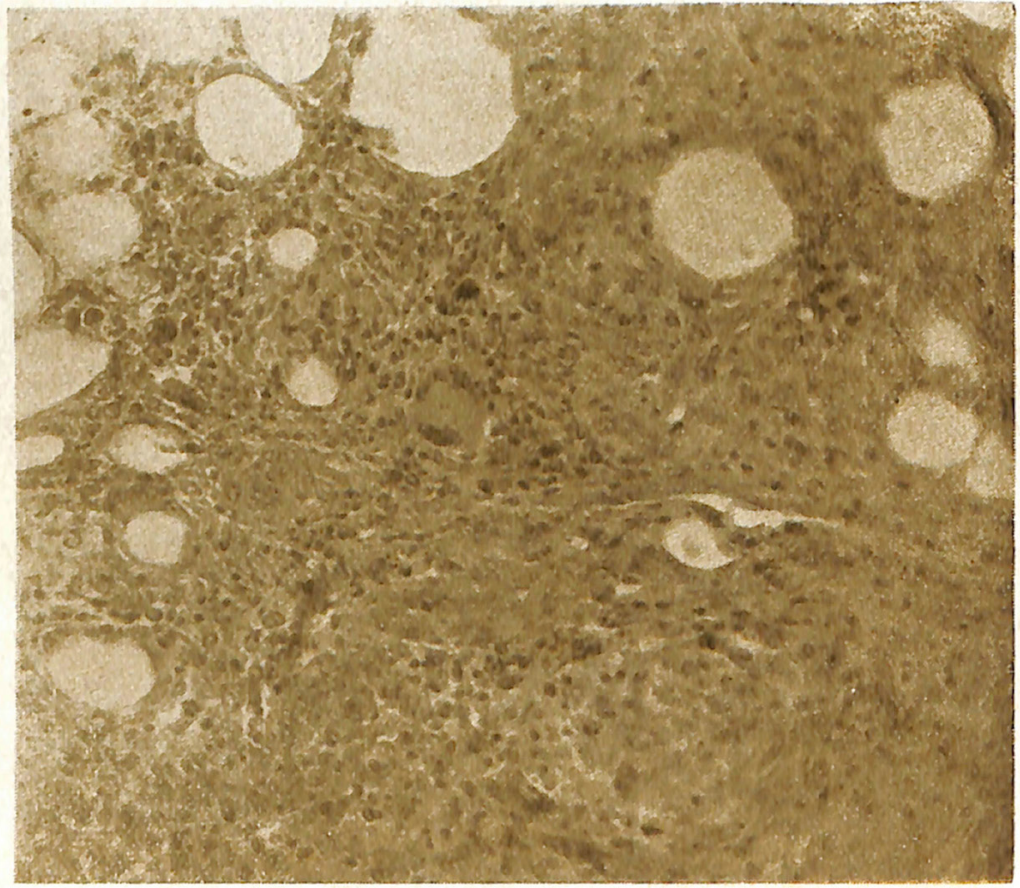
FIG. 20 - Chagoma de inoculação - aspéto microscopico 


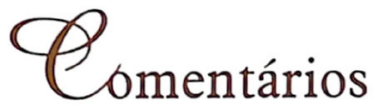

\title{
A Doença de Chagas Aguda sob o Olhar Pioneiro de Vianna Martins, Versiani e Tupinambá
}

\author{
Ana Maria fansen \\ André Luiz Rodrigues Roque \\ Laboratório de Biologia de Tripanosomatídeos \\ Instituto Oswaldo Cruz (IOC/Fiocruz)
}

Antes de discutirmos o artigo, é preciso entender as circunstâncias que o elevaram ao patamar dos 15 artigos históricos mais importantes para o estudo da doença de Chagas. É um trabalho do Instituto Ezequiel Dias e do Serviço de Estudo de Grandes Endemias do Instituto Oswaldo Cruz (Sege/IOC). O primeiro era dirigido por Otavio Magalhães e o segundo por Carlos Chagas Filho, em substituição ao seu irmão Evandro Chagas. Antônio Cardoso Fontes dirigia o IOC.

A publicação obedece ao estilo da época: após uma introdução com comentários, os autores descrevem caso por caso, minuciosa e detalhadamente, em um texto de agradável leitura. Ainda não havia agências de fomentos, Capes, Finep ou CNPq, os recursos eram poucos e as condições, precárias. A pesquisa no Brasil estava concentrada nos grandes centros São Paulo, Rio de Janeiro e Belo Horizonte e ainda longe de estar inserida no cenário internacional. As revistas vinham de navio, demoravam a chegar, e o intercâmbio entre pesquisadores e instituições de pesquisa não era comum.

A revista, de abrangência local, contém ainda dois trabalhos de Otavio Magalhães, professor de fisiologia, respectivamente sobre pasteurelas de animais e escorpionismo, o que demonstra o amplo espectro das questões abordadas por um mesmo pesquisador na época. A especialização ainda não havia chegado. Vale mencionar que Amilcar Vianna Martins estudou também entre outros, xistossomose e flebotomíneos.

\section{A IMPORTÂNCIA DO TRABALHO}

São vários os aspectos importantes dessa publicação, entre as quais a validação de um sinal clínico bastante peculiar nos casos agudos da doença, o complexo oftalmoganglionar, 
descrito pelo médico argentino e assistente de Salvador Mazza, Cecilio Romaña, em 1935, na IX Reunião da Mepra (Misión de Estudios de Patología Regional) em Mendoza, Argentina: o sinal de Romaña, assim denominado por Evandro Chagas em homenagem ao pesquisador, seu grande amigo. O sinal consiste em quadro ocular de porta de entrada da doença de Chagas aguda. Trata-se de um edema palpebral, unilateral, que envolve ingurgitamento ganglionar satélite (geralmente pré-auricular). Pode ocluir todo o olho e deixar, a longo prazo, um discreto fechamento da pálpebra afetada. Na verdade, o sinal fora visto (e fotografado) por Mazza e pelo próprio Carlos Chagas na Argentina e em Lassance, $M G$, sem receber a mesma atenção dada por Romaña. De fato, a descrição desse sinal por Vianna Martins e colabores como característico da forma aguda da doença representou um marco científico e epidemiológico, na medida em que facilitou enormemente o diagnóstico (Dias, 2006).

O conhecimento dos casos reportados pelo artigo, segundo o próprio Amilcar Vianna Martins em entrevista concedida a Ângelo Machado e Roberto B. de Carvalho, veio a partir de uma conversa corriqueira com um médico de Bambuí. Questionado por Martins "se não havia por lá indivíduos com um olho inchado", o médico, em um primeiro momento, respondeu que "não havia prestado atenção, mas que iria verificar". Poucos dias depois, esse mesmo médico encaminha uma menina com o olho inchado, a qual se verificou estar infectada. Era o primeiro caso agudo de doença de Chagas diagnosticado naquele município (Martins, 1990).

O estudo dos "25 casos agudos de Bambuí" (como ficou conhecida a publicação) representa a primeira descrição de um número expressivo de casos agudos no país desde o estudo conduzido por Carlos Chagas em Lassance. Para se ter uma idéia, durante sua trajetória, Chagas descreveu apenas 29 casos agudos e apenas outros quatro ou cinco haviam sido descritos até a publicação dos casos de Bambuí (Kropf, Azevedo \& Ferreira, 2000). Chagas foi, durante muito tempo, tremendamente questionado, e a doença estava longe de ser reconhecida como problema de saúde pública importante. A descoberta e o estudo minucioso dos casos de Bambuí chamaram a atenção para a doença, mostrando que se tratava de um sério agravo, provavelmente não apenas localizado em Bambuí, mas em grande parte do território nacional. Era o reconhecimento da moléstia de Chagas como doença de elevada importância em saúde pública.

Outro aspecto relevante é a visão abrangente do problema: Vianna Martins, Versiani e Tupinambá destacaram a necessidade de se implementar um amplo e abrangente programa de pesquisa sobre a doença de Chagas em todo o país, que incluísse o levantamento dos casos crônicos e presença do vetor e capacitação de pessoal "na maior parte do território nacional". Como conseqüência dessa publicação, Henrique Aragão, que assumira a direção do IOC em 1943, decide instalar naquele município, em novembro do mesmo ano, o Centro de Estudos e Profilaxia da Moléstia de Chagas (CEPMC), um posto do Instituto Oswaldo Cruz que será dirigido por Emmanuel Dias de 1943 a 1962. Segundo Kropf, Azevedo e Ferreira (2000), o trabalho desenvolvido em Bambuí foi responsável por garantir o reconhecimento da especificidade patológica e da relevância da doença como problema de saúde pública.

Os casos de Bambuí tiveram como principal característica a alta prevalência (72\%) de alterações no complexo oftalmoganglionar, os edemas palpebrais unilaterais que normalmente envolviam ingurgitamento ganglionar satélite. A nomenclatura "sinal de Romaña” é evitada pelos autores no texto, pois na época ainda não havia consenso: não se havia estabelecido se todo edema palpebral unilateral de origem chagásica deveria receber essa denominação, ou apenas o que indicasse a entrada no parasito pela própria conjuntiva ocular, como supunha Romaña. O fato é que esses achados vieram, de uma vez por todas, consolidar essa alteração 
como um instrumento diagnóstico importante quando a contaminação pelo parasito se processa no olho ou próximo a ele. Os autores também estavam atentos a outras localizações do chagoma de inoculação, como comprovam a exerese e o estudo e descrição de um chagoma de inoculação observado no antebraço de um jovem infectado. Tampouco escapou aos atentos observadores Vianna Martins, Versiani e Tupinambá o encontro de "um caso agudo benigno da doença": um menino de 10 anos cuja infecção foi comprovada por xenodiagnóstico, demonstrando assim que a infecção sem manifestações clínicas era possível.

O encontro de amastigotas em um corte de tireóide leva Vianna Martins e seus colaboradores a confirmar a tireoidite chagásica, manifestação descrita por Carlos Chagas e endossada por Miguel Couto. Mais tarde, essa manifestação seria reconhecida como um evento independente da presença do parasita, decorrente do caráter pan-infeccioso do Trypanosoma cruzi, capaz de colonizar praticamente qualquer tecido de seus múltiplos hospedeiros.

Outros aspectos importantes da epidemiologia da doença, muito pouco discutidos até então, aparecem de forma bastante enfática nesse trabalho. A destacar está o caráter regional da doença de Chagas, concluído com base na escassez de casos agudos em Lassance: "a moléstia (de Chagas) assume diferentes aspectos nas diversas regiões onde existe levantando-se assim novos e interessantes problemas". Os autores deixam claro que generalizações e medidas de controle baseadas em "cálculos teóricos sobre o número de cafuas (casas de pau-a-pique) existentes no Brasil e sobre a percentagem de seus habitantes que devem estar infectados" são insuficientes; era necessário adotar medidas abrangentes. Nada mais atual, como atestam os recentes surtos de doença de Chagas por ingestão de alimentos contaminados com formas infectantes do parasita. Adicionalmente, vale mencionar que o caráter regional da doença de Chagas representa, até hoje, um quebra-cabeça não resolvido.

Vianna Martins, Versiani e Tupinambá enfatizam ainda a necessidade da sensibilização e capacitação de médicos e laboratoristas, a serem conduzidas durante as expedições no campo, para o diagnóstico precoce da doença. Esse, aliás, era o principal objetivo almejado pelos autores quando da publicação do artigo. A criação do CEPMC três anos mais tarde era a confirmação de que esse grande objetivo havia sido alcançado.

Segundo Dias (1982), os estudos acerca da doença de Chagas em Bambuí, iniciados por Vianna Martins e colaboradores em 1940, podem ser divididos em três períodos: (i) o inicial (1940-1956), caracterizado por altos índices de triatomíneos com infecção natural pelo T. cruzi, presença maciça de Triatoma infestans e elevados índices de transmissão ao homem; (ii) o intermediário (1957-1970), que se inicia com os trabalhos de desinsetização para redução do T. infestans e da transmissão da doença ao homem, apresentando momentos de reinfestação domiciliar em algumas áreas rurais; (iii) um terceiro período, cujos marcos são os anos de 1971, pela consolidação da profilaxia antivetorial, e 1974, pela implantação da Vigilância Epidemiológica. Nesse período ocorrem o controle do T. infestans e a interrupção da transmissão da doença de Chagas ao homem, com o surgimento esporádico de adultos do Panstrongylus megistus nas casas rurais (Fernandes et al., 2004).

Mais tarde, o próprio Vianna Martins seria vítima da doença de Chagas. Segundo seu relato (na entrevista supracitada), a infecção se deu em uma viagem à serra do Cipó, em Minas Gerais, onde dormira em uma pensão. Apesar de ter dormido em uma cama no centro do quarto, por achar que assim seria um 'alvo' menos provável, Vianna Martins acredita ter sido picado por um barbeiro atraído pela luz. Seis dias depois, sua febre teve início e capturas naquela pensão mostraram a presença de barbeiros contaminados. Durante mais de vinte anos Vianna Martins não sentiu absolutamente nada, até o aparecimento de uma dilatação do esôfago, que passou a incomodá-lo bastante. O cientista faleceu em 1990, aos 82 anos. 


\title{
REFERENNCIAS
}

DIAS, J. C. P. Doença de Chagas em Bambuí, Minas Gerais, Brasil: estudo clínico-epidemiológico a partir da fase aguda, entre 1940 e 1982, 1982. Tese de Doutorado, Belo Horizonte: Universidade Federal de Minas Gerais.

DIAS, J. C. P. A contribuição de Salvador Mazza, Cecilio Romaña e dos médicos argentinos ao estudo da doença de Chagas, 2006. Disponível em: Portal Fiocruz de Doença de Chagas, <www.fiocruz.br/ chagas/cgi/cgilua.exe/sys/start.htm?sid=54>. Acesso em: 1 jun. 2009.

FERNANDES, A. J. et al. Inter-relações entre os ciclos de transmissão do Trypanosoma cruzi no Município de Bambuí, Minas Gerais, Brasil. Cadernos de Saúde Pública, 10(4): 473-480, 1994.

KROPF, S. P.; AZEVEDO, N. \& FERREIRA, L. O. Doença de Chagas: a construção de um fato científico e de um problema de saúde pública no Brasil. Ciências e Saúde Coletiva, 5(2): 347-365, 2000.

MARTINS, A. V. Entrevista concedida a Ângelo Machado e Roberto B. de Carvalho, 1990. Canal Ciência. Disponível em: Portal Ibict, <ww.canalciencia.ibict.br/notaveis/txt.php?id=8>. Acesso em: 29 maio 2009.

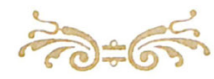

\section{De Volta ao Sertão Mineiro: 25 casos agudos em Bambuí e a renovação dos estudos sobre a doença de Chagas no Brasil}

\author{
Simone Petraglia Kropf \\ Nara Azevedo \\ Programa de Pós-Graduação em História das Ciências e da Saúde \\ Casa de Oswaldo (COC/Fiocruz)
}

"Sobre 25 casos agudos de moléstia de Chagas observados em Minas Gerais", artigo de Amilcar Vianna Martins, Valdemar Versiani e Antonio Tupinambá, publicado nas Memórias do Instituto Biológico Ezequiel Dias nos volumes de 1939-1940, descreve um conjunto de casos da tripanossomíase americana diagnosticados em Bambuí, município do oeste mineiro. O texto, que constitui um marco nos estudos sobre a doença de Chagas no Brasil, foi fruto da cooperação entre o Serviço de Estudo das Grandes Endemias (Sege), do Instituto Oswaldo Cruz (IOC), e o Instituto Biológico Ezequiel Dias (Ibed, criado em 1907 como filial do IOC em Belo Horizonte, incorporado ao governo estadual em 1936, e atual Fundação Ezequiel Dias). Ao promover uma ampla mobilização científica e social em torno da doença, o trabalho representou uma contribuição decisiva para a renovação do interesse pelo tema e para a superação das dúvidas que existiam, desde a década de 1920 , sobre a importância médico-social e a distribuição geográfica da doença de Chagas no país.

O trabalho de Martins e seus colaboradores é indissociável da relevante atuação do Sege no sentido de dar continuidade aos estudos sobre endemias no IOC após o falecimento de Carlos Chagas, em novembro de 1934. Criado em 1937 por Evandro Chagas (filho mais velho de Carlos Chagas), e funcionando no Hospital de Manguinhos, o Sege deve ser compreendido em sua inserção no contexto histórico-social brasileiro do pós-1930. Ainda 
que a modernização capitalista preconizada pelo governo de Getulio Vargas privilegiasse o mundo urbano-industrial, o desenvolvimento rural era tido como elemento relevante para assegurar o abastecimento do mercado interno, que sustentaria o novo modelo econômico de 'substituição de importações'. Conjugada a essa diretriz, estava a centralidade conferida pelo Estado ao tema do trabalho, considerado valor primordial para a construção de uma 'nova nação', que requeria trabalhadores sãos, fortes e produtivos, nas cidades e no campo (Gomes, 1988). Em Minas Gerais, a preocupação das elites com a estagnação econômica do estado, sobretudo em comparação ao vizinho paulista, tornava-as sensíveis a programas destinados a aumentar a produtividade no campo, minimizar o exodo rural e recuperar a tradicional vocação agrícola do estado (Dulci, 1999).

Naquele contexto, a participação de pesquisadores do Sege na campanha contra o Anopheles gambiae (vetor da malária), realizada em 1939-1940 pela Fundação Rockefeller e pelo Ministério da Educação e Saúde no nordeste do país - reconhecida como fato notável da saúde pública brasileira e internacional (Packard \& Gadelha, 1994) -, garantiu ao serviço dirigido por Evandro Chagas grande visibilidade e força política. Isso gerou novas condições para o estabelecimento de acordos com os governos estaduais a fim de implementar ações de combate às principais endemias no país.

Em outubro de 1939, o Sege firmou um plano para pesquisar a doença de Chagas em Minas Gerais, em cooperação com o Ibed. Seria conduzido por Amilcar Vianna Martins, investigador desse instituto e professor de parasitologia da Faculdade de Medicina de Belo Horizonte, juntamente com dois assistentes - Valdemar Versiani e Antonio Tupinambá - com quem Martins vinha realizando estudos sobre os vetores da doença no Estado. ${ }^{1}$ A expectativa era a de que, ampliado para outras regiões, esse empreendimento poderia "dentro de prazo relativamente curto, fornecer noção exata da distribuição geográfica da tripanossomíase americana no Brasil e idéia precisa do verdadeiro significado médicosocial desta moléstia no país". ${ }^{2}$

\footnotetext{
'Amilcar Vianna Martins (1907-1990) nasceu em Belo Horizonte e foi um dos grandes líderes da parasitologia mineira. Ingressou, em 1924, na Faculdade de Medicina de Belo Horizonte (FMBH), trabalhando no Instituto Biológico Ezequiel Dias (Ibed) como auxiliar acadêmico e, depois, pesquisador. Em 1930, tornou-se professor assistente de fisiologia daquela faculdade. Em 1939, foi aprovado em concurso para livre-docente da cadeira de parasitologia. Um ano depois, tornou-se professor catedrático de zoologia e parasitologia da Faculdade de Odontologia e Farmácia da Universidade de Minas Gerais. Em 1943, serviu à Força Expedicionária Brasileira na Itália. Em 1947, desligou-se do Instituto Químico Biológico (antigo Ibed), para chefiar o Serviço de Endemias Rurais da Secretaria de Saúde de Minas Gerais, onde permaneceu até 1949. Em 1952, passou a atuar como perito em doenças parasitárias da Organização Mundial da Saúde (OMS). Entre 1956 e 1958, dirigiu o Instituto Nacional de Endemias Rurais (INERu), subordinado ao Departamento Nacional de Endemias Rurais (DNERu), criado no Ministério da Saúde em 1956. O Centro de Pesquisas de Belo Horizonte, origem do atual Centro de Pesquisas René Rachou da Fiocruz, em cuja criação Martins desempenhou papel decisivo, foi um dos órgãos do INERu. Entre 1958 e 1960, foi diretor do Instituto Oswaldo Cruz (IOC) e, entre 1960 e 1961, esteve à frente do DNERu. Em 1966, assumiu a direção do Instituto de Ciências Biológicas da Universidade Federal de Minas Gerais e, no ano seguinte, tornou-se diretor do Departamento de Parasitologia desse instituto. Em 1969, foi aposentado compulsoriamente pelo ato institucional $n^{\circ} 5$ (AI-5), retornando às suas funções docentes em 1979. Faleceu em 1990. Ver Azevedo \& Kropf (2007).

2 Serviço de Estudo das Grandes Endemias. Exposição ao Sr. Ministro da Educação e Saúde destinada a modificar o orçamento para o Serviço em 1940. Rio de Janeiro, de 9 de novembro de 1939. Arquivo Gustavo Capanema, Série Ministério da Educação e Saúde/Saúde e Serviço Social, GC h 1935.05.27. Esse arquivo encontra-se sob a guarda do Centro de Pesquisa e Documentação de História Contemporânea do Brasil/Fundação Getulio Vargas (Cpdoc/FGV). O plano encontra-se publicado em Martins, Versiani \& Tupinambá (1940: 286-287).
} 
Em julho de 1940, os pesquisadores publicaram os primeiros resultados. Analisando dados de 118 municípios mineiros, concluíram que "os 'barbeiros' parecem existir em todo o território do Estado com exceção de pequenas áreas” (Martins, Versiani \& Tupinambá, 1940: 290) e que, no caso das espécies mais freqüentes, era alta a percentagem de presença do Trypanosoma cruzi, o que indicava que a ocorrência de casos humanos era bastante provável em grande parte do território. Segundo Evandro Chagas, esse trabalho constituía "o primeiro passo no sentido do estudo racional da epidemiologia da doença de Chagas no Brasil"." Alguns meses depois, os pesquisadores encontraram dois casos agudos (nos municípios de Grão-Mogol e Luz), os primeiros registrados em Minas Gerais depois dos estudos de Carlos Chagas publicados em 1916 (Martins \& Tupinambá, 1940).

Comentando a dificuldade em diagnosticar a doença num estado em que sua presença sempre havia sido estimada como extremamente alta, os autores reforçaram a importância da nova orientação que, desde a atuação da Misión de Estudios de Patología Regional Argentina (Mepra), criada por Salvador Mazza em 1926, vinha permitindo superá-la: a preocupação de que a doença deixasse de ser tema de especialistas e passasse a atrair o interesse também dos clínicos, sobretudo do interior, de modo a que estes colaborassem no mapeamento da sua ocorrência (Sierra-Iglesias, 1990; Zabala, 2007; Kropf, 2008). A conjuntivite esquizotripanósica unilateral (conhecida como sinal de Romaña) e o chagoma de inoculação, descritos, respectivamente, por Cecílio Romaña e por Salvador Mazza, em 1935 e 1936, foram cruciais para tal perspectiva, por constituírem sinais indicativos da fase aguda da infecção, de fácil reconhecimento. A partir de então, seriam identificadas centenas de casos agudos na Argentina e em outros países (Dias, 1997).

Um aspecto central da atuação do Sege - que, com o falecimento precoce de Evandro Chagas, em novembro de 1940, foi assumido por Carlos Chagas Filho até ser incorporado, em 1942, na Divisão de Estudo de Endemias do IOC - foi justamente o empenho em divulgar amplamente os métodos de diagnóstico clínico da doença (sobretudo o sinal de Romaña)entre os clínicos, em especial os residentes no interior (Kropf, 2008). Em seu estudo sobre a distribuição geográfica dos triatomíneos em Minas Gerais, Martins e seus colaboradores enviaram circulares para "médicos, organizações sanitárias, professores, prefeitos municipais e fazendeiros do interior", informando-lhes sobre como diagnosticar a doença e solicitando que lhes remetessem barbeiros para exame (Martins, Versiani \& Tupinambá, 1940: 287).

A descoberta dos casos da tripanossomíase em Bambuí resultou desse processo de divulgação. Em 1940, Antonio Torres Sobrinho, clínico daquela região, foi consultar-se em Belo Horizonte com Amilcar Martins, que lhe falou a respeito do "sinal do olho" e da importância de buscar casos agudos da doença no estado. Martins disse ao médico que, em função das pesquisas realizadas pelo Ibed, já havia examinado um barbeiro infectado pelo T. cruzi proveniente de Bambuí. Em outubro daquele ano, Sobrinho atendeu em seu consultório uma menina com características clínicas da fase aguda, entre elas o inchaço no olho. Remetidos os dados a Belo Horizonte, a resposta não tardou: a menina Maria Albina era o primeiro caso confirmado em Bambuí. Sobre aqueles dias, relembra Sobrinho:

\footnotetext{
${ }^{3}$ Carta de Evandro Chagas a Amilcar Vianna Martins, Rio de Janeiro, 20 de fevereiro de 1940. Fundo Evandro Chagas, grupo: pesquisa; atividade: divulgação de resultados; função: diretor do Hospital Oswaldo Cruz/ superintendente do Sege/orientação técnica e científica do Ipen; notação BR RJCOC EC 04.144. Esse arquivo encontra-se sob a guarda da Casa de Oswaldo Cruz (COC/Fiocruz).
} 
O movimento de casos que se seguiu foi tão grande que, de 9 de outubro de 1940 a 21 de março de 1941, apenas em seis meses e meio, só pelas minhas mãos passaram dezesseis casos agudos, fora os que foram observados pelos colegas do Hospital. E quase todos foram remetidos para o devido estudo aos Institutos Oswaldo Cruz no Rio e Ezequiel Dias em Belo Horizonte. ${ }^{+}$

Em dezembro de 1941, foram contabilizados 25 casos, descritos minuciosamente no trabalho publicado nas Memórias do Instituto Biológico Ezequiel Dias (Martins, Versiani \& Tupinambá, 1939-1940). ${ }^{5}$ Tratava-se de número expressivo, visto que, em revisão da literatura publicada três anos antes, o parasitologista inglês Warrington Yorke (1937) assinalara que no Brasil haviam sido descritos até então 33 casos agudos de infecção (29 apresentados nos trabalhos de Carlos Chagas e quatro em São Paulo) e, fora do país, 113 casos.

O trabalho de Martins e colaboradores era uma resposta àqueles que, desde a célebre polêmica na Academia Nacional de Medicina, nos anos 1920, duvidaram das afirmações de Chagas sobre a importância epidemiológica da doença. ${ }^{6}$ Numa alusão direta aos que haviam qualificado a tripanossomíase como "raridade nosográfica" (ANM, 1923: 681) 7 e ao descrédito que, a partir de então, havia cercado o assunto, os autores declaram:

Já começa a moléstia a chamar novamente a atenção dos poderes públicos e a entrar na cogitação dos clínicos, principalmente os do interior. Consideramos urgente mostrar a verdadeira importância da moléstia de Chagas, provar objetivamente, por meio de observaçōes numerosas, de que não se trata de moléstia rara, curiosidade nosológica, que ataca esporadicamente sertanejos de baixo nível econômico. (Martins, Versiani \& Tupinambá, 1939-1940: 3-4).

Para os pesquisadores, era fundamental a disseminação, entre os clínicos do interior, dos conhecimentos que permitiam o diagnóstico da infecção, sobretudo em sua fase aguda. Comemorando os resultados "absolutamente animadores" colhidos nessa empreitada, afirmam: "Na zona mais trabalhada - o município de Bambuí - já o diagnóstico clínico e mesmo a sua confirmação pelas provas de laboratório, é feito com a maior segurança pelos médicos locais", que, por estarem "em contato direto com as populações rurais", deveriam ser alvo de uma relevante "obra de propaganda" (Martins, Versiani \& Tupinambá, 1939-1940: 4, 9).

Do ponto de vista institucional, a realização e a repercussão do trabalho de Martins, Versiani e Tupinambá produziram um resultado decisivo para a continuidade dos estudos sobre a doença de Chagas, bem como para o processo de seu reconhecimento científico e social: a criação, em 1943, em Bambuí, do Centro de Estudos e Profilaxia da Moléstia de

${ }^{4}$ Discurso de Antonio Torres Sobrinho no Hospital Nossa Senhora do Brasil em Bambuí. Bambuí, 21 de dezembro de 1979, p. 2-3. Fundo Centro de Pesquisas René Rachou, Seção Posto Avançado de Pesquisas Emmanuel Dias, caixa 03, maço 7. Esse arquivo encontra-se sob a guarda da COC/Fiocruz. Um dos fatores apontados por Martins, Versiani e Tupinambá (1939-1940: 5) para o sucesso dos estudos em Bambuí era justamente a existência de "um bem montado hospital na cidade", que permitia o afluxo de doentes da regiāo e a realização de exames "com grande cuidado".

${ }^{5}$ Embora a data de publicação do referido trabalho seja 1939-1940, ele corresponde às observações feitas pelos autores até dezembro de 1941, e foi entregue para publicação em março de 1942.

- Sobre a polêmica em torno da doença de Chagas na década de 1920, ver Benchimol \& Teixeira (1993); Chagas Filho (1993); Coutinho (1999); Kropf, Azevedo \& Ferreira (2003) e Kropf (2009).

${ }^{7}$ A expressão foi usada por Afrânio Peixoto, principal opositor de Chagas, na polêmica travada na Academia Nacional de Medicina (ANM, 1923: 681). 
Chagas (CEPMC), posto do IOC dirigido por Emmanuel Dias (discípulo e afilhado de Carlos Chagas) até seu falecimento em $1962 .^{8}$

Contando com o forte apoio do então diretor do IOC, Henrique Aragão, o CEPMC se dedicaria a ampliar o estudo clínico da fase crônica da doença. Graças, sobretudo, à expertise do cardiologista Francisco Laranja, foram produzidos dados eletrocardiográficos, radiológicos e clínicos que levaram à individualização da cardiopatia chagásica crônica como principal expressão clínica da doença. Além disso, num contexto em que os inseticidas de ação residual, como o DDT, estavam em evidência no cenário internacional (Farley, 2004), ali foram produzidas as bases técnicas para a primeira campanha de combate à endemia, inaugurada pelo Ministério da Educação e Saúde em Uberaba, em 1950, mediante a aplicação de BHC nas moradias. Emmanuel Dias se tornaria um dos principais líderes da mobilização em prol do reconhecimento científico e social da endemia chagásica como "problema continental", a ser tratado como prioridade nas políticas públicas de saúde.

Na perspectiva da história da ciência, a atuação de Martins e seus colaboradores, assim como a dos demais médicos e cientistas empenhados na renovação da pesquisa sobre a doença de Chagas naquele período, é exemplar dos meandros do processo de construção e de legitimação de um fato científico no qual a dimensão cognitiva é indissociável da dimensão social. Os 'fatos' da ciência resultam da produção de um consenso em torno de enunciados científicos, cuja validação depende de sua propagação no tempo e no espaço pelo maior número possível de 'aliados'. Para tanto, os produtores desses fatos acionam múltiplos mecanismos e estratégias persuasivas, em um processo de negociação que necessariamente envolve cientistas e outros atores e esferas da vida social. É por meio dessa associação de interesses que o conhecimento científico se estabelece e se certifica como expressão da 'natureza'. Nesse sentido, define-se como uma atividade sociocognitiva e política. Política não apenas porque influenciada pelas relações de poder, mas porque a produção do conhecimento constitui em si uma forma de se fazer política, e de agir sobre o mundo (Latour \& Woolgar, 1979; Latour, 2000).

Ao produzir o consenso em relação a certos enunciados a respeito da tripanossomíase americana, aquele grupo de médicos e cientistas promoveu a continuidade do trabalho de Carlos Chagas, atraindo novas gerações de pesquisadores e constituindo uma tradição científica que, cem anos depois da descoberta da doença, permanece atuante e vigorosa. As estratégias políticas de mobilização e convencimento utilizadas pelos 'pioneiros' seguem válidas hoje, para que a sociedade, os governos, os agentes econômicos e as agências internacionais reconheçam a importância de apoiar as pesquisas e as ações de combate da doença de Chagas e de outras 'doenças negligenciadas' no século XXI.

\section{REFERÊNCIAS}

ACADEMIA NACIONAL DE MEDICINA. Sessão de 16 de novembro de 1923. Boletim da Academia de Medicina, 657-691, 1923.

AZEVEDO, N. \& KROPF, S. P. Ciência, saúde e vida pública. In: KLEIN, L. (Org.). Professor Amilcar Vianna Martins: ciência para a saúde. Rio de Janeiro: Fundação Oswaldo Cruz, 2007.

\footnotetext{
${ }^{8}$ Emmanuel Dias esteve associado ao Sege, tendo escrito vários artigos divulgando o sinal de Romaña entre os médicos, sobretudo do interior (Dias, 1939; Chagas \& Dias, 1941). Sobre o Ibed, ver Klein \& Thielen (2003) e Starling, Germano \& Marques (2007). Sobre o Sege e o CEPMC, ver Kropf, 2005, 2008, 2009. Sobre Emmanuel Dias, ver Kropf (2009) e Dias (2009).
} 
BENCHIMOL, J. L. \& TEIXEIRA, L. A. Cobras, Lagartos \& Outros Bichos: uma história comparada dos institutos Oswaldo Cruz e Butantan. Rio de Janeiro: Editora UFRJ, 1993.

CHAGAS, E. \& DIAS, E. A propósito do sinal de Romaña. O Hospital, 19(2): 185-189, 1941.

CHAGAS FILHO, C. Meu Pai. Rio de Janeiro: Casa de Oswaldo Cruz/Fiocruz, 1993.

COUTINHO, M. Ninety years of Chagas disease: a sucess story at the periphery. Social Studies of Science, 29(4): 519-549, 1999.

DIAS, E. O sinal de Romaña e sua influência na evolução dos conhecimentos sobre a moléstia de Chagas. Brasil Médico, 53 (42): 965-970, 1939.

DIAS, J. C. P. Cecílio Romaña, o sinal de Romaña e a doença de Chagas. Revista da Sociedade Brasileira de Medicina Tropical, 30(5): 407-413, 1997.

DIAS, J. C. P. (Org.). Dr. Emmanuel Dias (1908-1962). Rio de Janeiro: Fundação Oswaldo Cruz, 2009.

DULCI, O. S. Política e Recuperação Econômica em Minas Gerais. Belo Horizonte: Editora UFMG, 1999.

FARLEY, J. To Cast out Disease: a history of the International Health Division of the Rockefeller Foundation (1913-1951). New York: Oxford University Press, 2004.

GOMES, A. M. de C. A Invenção do Trabalhismo. Rio de Janeiro, São Paulo: Iuperj, Vértice, 1988.

KLEIN, L. \& THIELEN, E. A ciência das doenças nas Gerais: da filial de Manguinhos ao Centro de Pesquisas René Rachou. In: CENTRO DE PESQUISAS RENÉ RACHOU. Centro de Pesquisas René Rachou: produção científica (1980-1999). Belo Horizonte: Centro de Pesquisas René Rachou, 2003.

KROPF, S. P. Ciência, saúde e desenvolvimento: a doença de Chagas no Brasil (1943-1962). Tempo, 10(19): 107-124, 2005.

KROPF, S. P. En busca de la enfermedad del Brasil: los médicos del interior y los estudios sobre el mal de Chagas (1935-1956). In: Carbonetti, A. \& GONZÁLEZ-LEANDRI, R. (Orgs.). Historias de Salud y Enfermedad en América Latina, Siglos XIX y XX. Córdoba: Universidad Nacional de Córdoba, Conicet, 2008.

KROPF, S. P. Doença de Chagas, Doença do Brasil: ciência, saúde e nação (1909-1962). Rio de Janeiro: Editora Fiocruz, 2009.

KROPF, S. P.; AZEVEDO, N. \& FERREIRA, L. O. Biomedical research and public health in Brazil: the case of Chagas' disease (1909-1950). Social History of Medicine, 16(1): 111-129, 2003.

LATOUR, B. Ciência em Ação: como seguir cientistas e engenheiros sociedade afora. São Paulo: Unesp, 2000.

LATOUR, B. \& WOOLGAR, S. A Vida de Laboratório: a construção dos fatos científicos. Rio de Janeiro: Relume Dumará, 1997.

MARTINS, A. V. \& TUPINAMBÁ, A. Sobre dois casos agudos de moléstia de Chagas observados em Minas Gerais, Brasil. Brasil Médico, 54(51): 839-841, 1940.

MARTINS, A. V.; VERSIANI, V. \& TUPINAMBÁ, A. Sobre 25 casos agudos de moléstia de Chagas observados em Minas Gerais. Separata de Memórias do Instituto Ezequiel Dias, 3/4: 3-47, 1939-1940.

MARTINS, A. V.; VERSIANI, V. \& TUPINAMBÁ, A. Estudos sobre a tripanossomíase americana em Minas Gerais, Brasil. Memórias do Instituto Oswaldo Cruz, 35(2): 285-301, 1940.

PACKARD, R. \& GADELHA, P. A land filled with mosquitos: Fred L. Soper, the Rockefeller Foundation and the Anopheles gambiae invasion of Brazil. Parassitologia, 36: 197-213, 1994.

SIERRA-IGLESIAS, J. P. Salvador Mazza, su Vida e su Obra, Redescubridor de la Enfermedad de Chagas. San Salvador de Jujuy: Universidad Nacional de Jujuy, 1990.

STARLING, H. M. M.; GERMANO, L. B. de P. \& MARQUES, R. de C. (Orgs.). Fundação Ezequiel Dias: um século de promoção e proteção à saúde. Belo Horizonte: Editora UFMG, 2007. 
ZABALA, J. P. Producción y Uso de Conocimientos Cientificos Vinculados a la Enfermedad de Chagas. Argentina, 1915-2000, 2007. Tese de Doutorado, Buenos Aires, Paris: Facultad Latinoamericana de Ciencias Sociales-Argentina, Université Paris 1 Panthéon-Sorbonne.

YORKE, W. Chagas' disease: a critical review. Tropical Diseases Bulletin, 34(4): 275-300, 1937. 